\title{
Synthesis, Affinity for Complementary RNA and DNA, and Enzymatic Stability of Triazole-Linked Locked Nucleic Acids (t-LNAs)
}

\author{
Pawan Kumar, ${ }^{\dagger, \S \odot ~ L y n d a ~ T r u o n g, ~}{ }^{\dagger}$ Ysobel Ruth Baker, $^{\dagger}$ Afaf Helmy El-Sagheer, ${ }^{\dagger, \ddagger \odot}$ and Tom Brown ${ }^{*}, \dagger \odot$ \\ ${ }^{\dagger}$ Department of Chemistry, University of Oxford, 12 Mansfield Road, Oxford OX1 3TA, U.K. \\ ${ }^{\ddagger}$ Chemistry Branch, Department of Science and Mathematics, Faculty of Petroleum and Mining Engineering, Suez University, Suez \\ 43721, Egypt
}

Supporting Information

ABSTRACT: Dinucleoside phosphoramidites containing a triazole internucleotide linkage flanked by locked nucleic acid (LNA) were synthesized and incorporated into oligonucleotides (ONs). ONs bearing both LNA and triazole at multiple sites were obtained and their biophysical properties including enzymatic stability and binding affinity for RNA and DNA targets were studied. t-LNAs with four incorporations of a dinucleoside monomer having LNA on either side of the triazole linkage bind to their RNA target with significantly higher affinity and greater specificity than unmodified oligonucleotides, and are remarkably stable to nuclease degradation. A similar but reduced effect on enzymatic stability and binding affinity was noted for LNA only on the 3 '-side of the triazole linkage. Thus, by combining unnatural triazole linkages and LNA in one unit ( $\mathrm{t}-\mathrm{LNA}$ ), we produced a promising class of ONs with reduced anionic charge and potential for antisense applications.

\section{INTRODUCTION}

Antisense oligonucleotides (ASO) are short single-stranded nucleic acids (typically 15-25 nucleotides in length) that bind to their RNA target in a sequence-specific manner and modulate translation (protein synthesis) or RNA splicing. ${ }^{1}$ Unmodified natural DNA or RNA strands are not optimum antisense candidates because of their poor serum stability and modest binding affinity for RNA. Chemically modified nucleic acids $^{2-4}$ offer a promising alternative to their unmodified counterparts and have been extensively studied since the ASO concept was first introduced. ${ }^{5}$ Some of these modifications possess favorable biophysical properties, which is evident from the recent success in the clinic. ${ }^{6,7}$ Despite this, ideal antisense candidates, with the desired characteristics of efficient unaided cellular uptake, long serum half-life and high RNA binding affinity and target specificity, remain elusive and there is a need to explore new chemically modified nucleic acids.

Recently, we have been interested in backbone-modified oligonucleotides (ONs) with a special focus on triazole-linked nucleic acids. ${ }^{8}$ A series of studies over the past decade led us to a highly versatile and biocompatible six-atom triazole linkage (monomer W, Figure 1). ${ }^{9-12}$ This and other triazole linkages ${ }^{13,14}$ have been shown to improve the stability of modified ONs to degradation by DNase enzymes. ${ }^{14-17}$ Unfortunately, the thermal stability of duplexes carrying triazole internucleotide linkages is compromised by the modified backbone. ${ }^{13,15,17-23}$ This imposes a restriction on the use of triazole-linked oligonucleotides in antisense applications, even though they possess the favorable properties of resistance to enzymatic degradation and the lack of anionic charge that can

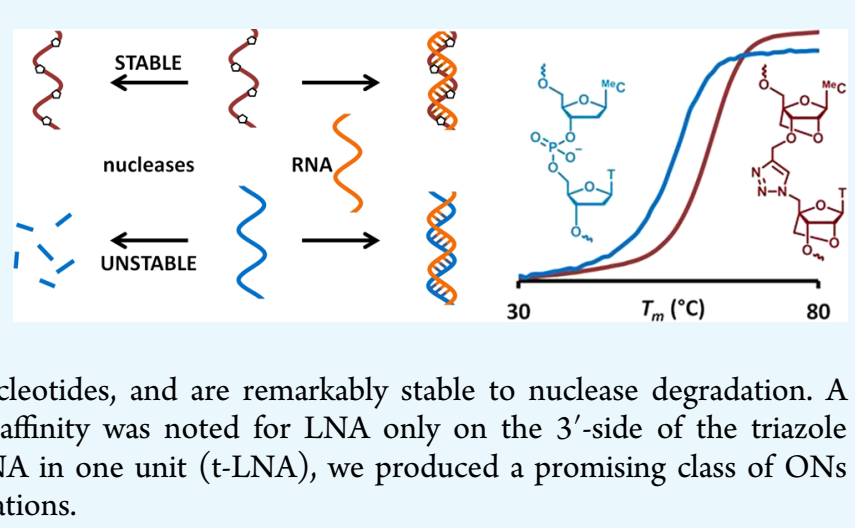

hinder cell uptake of natural DNA. Building on the seminal work by Wengel, ${ }^{24}$ we have previously shown ${ }^{16}$ that introducing a conformationally restricted locked nucleic acid (LNA) ${ }^{25-27}$ next to the triazole linkage (monomers $\mathbf{X}$ and $\mathbf{Z}$, Figure 1) counterbalances the reduction in binding affinity caused by the triazole, resulting in modified ONs that bind to their RNA target with affinity similar to unmodified ONs. Interestingly, Watts et al. found in contrast that LNA does not stabilize duplexes containing a more rigid four-atom triazole linkage internally. ${ }^{15}$ Thus, the biocompatible six-atom triazole linkage and LNA (monomers $\mathbf{X}$ and $\mathbf{Z}$, Figure 1) is a promising combination and warrants further investigation.

In our previous study, we incorporated monomers $\mathbf{W}-\mathbf{Z}$ into oligonucleotides by ligating together two short ONs, one with a $5^{\prime}$-azide group and the other with a 3 -propargyl group. ${ }^{16}$ This approach was chosen for ease of $\mathrm{ON}$ synthesis. However, multiple incorporations of the triazole linkage into short ONs and the introduction of the linkage at the ends of ONs is not practical using this strategy. Here, we report the synthesis of dinucleoside phosphoramidites containing the triazole linkage flanked by LNA as suitable building blocks for the efficient and flexible incorporation of monomers $\mathbf{W}-\mathrm{Z}$ into $\mathrm{ONs}$ using standard solid phase phosphoramidite DNA synthesis methodology. Using this approach, 13-mer ONs with 1, 2, or 4 incorporations of the modified monomers $\mathbf{W}-\mathbf{Z}$ were readily obtained, enabling us to study their enzymatic stability and

Received: May 22, 2018

Accepted: May 30, 2018

Published: June 27, 2018 
A

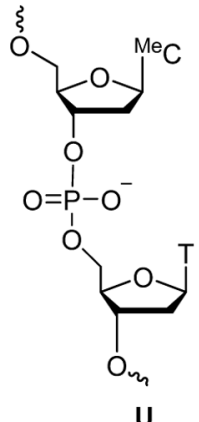

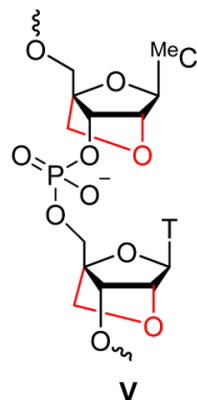

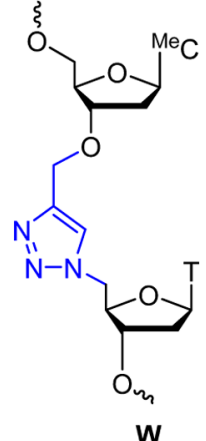

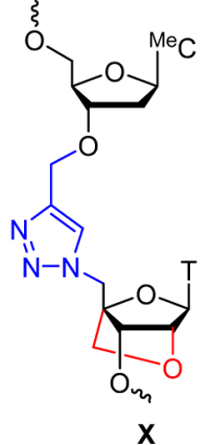

$\mathbf{X}$
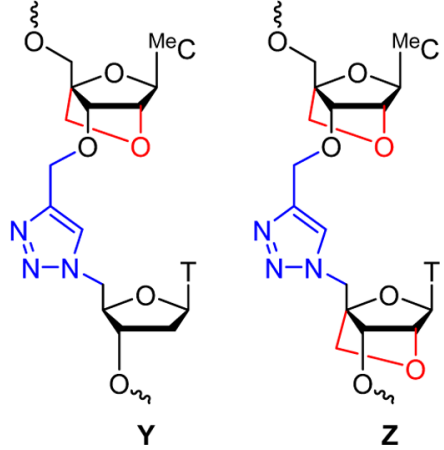

B

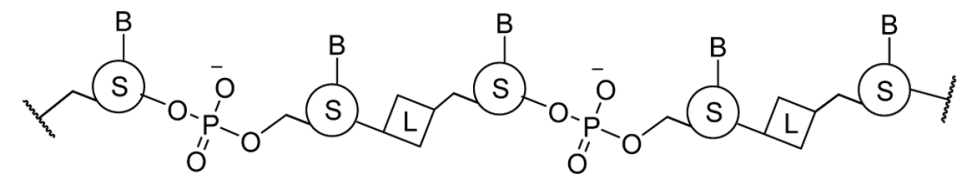

Figure 1. (A) Structures of phosphodiester and triazole-linked DNA and LNA backbones investigated in this study. U: Phosphodiester-linked DNA. V: Phosphodiester-linked LNA. W: Triazole-linked DNA. X: Triazole-linked 3'-LNA. Y: Triazole-linked 5'-LNA. Z: Triazole-linked 3',5'-LNA. T = thymin-1-yl, ${ }^{\mathrm{Me}} \mathrm{C}=5$-methylcytosin-1-yl. (B) The general principle explored in this study, where $\mathrm{B}=$ nucleobase, $\mathrm{S}=$ modified sugar (e.g., LNA), $\mathrm{L}=$ modified DNA backbone (e.g., triazole). Enzymatic degradation of such structures cannot give rise to monomer units that can enter the mononucleotide triphosphate pool in cells. Hence, the modifications cannot be incorporated into genomic DNA or RNA.

hybridization (duplex-forming) properties. Monomer $\mathbf{Z}$ stands out among those tested; ONs carrying four incorporations of $\mathbf{Z}$ are strikingly resistant toward nucleolytic degradation, and show enhanced binding to RNA targets with improved affinity and specificity relative to unmodified ONs. Thus, the combination of LNA and the triazole linkage provides a new class of potentially significant antisense oligonucleotide candidates.

\section{RESULTS AND DISCUSSION}

Chemical Synthesis. First, nucleosides with a $3^{\prime}-O$ propargyl group and $5^{\prime}$-azido group were prepared (Scheme $1)$. Accordingly, $5^{\prime}-O-\left(4,4^{\prime}\right.$-dimethoxytrityl)-3'-O-propargylLNA 5-methylcytosine $(\mathbf{1})^{16}$ and $5^{\prime}-O-\left(4,4^{\prime}\right.$-dimethoxytrityl)$3^{\prime}$-O-propargyl-5-methylcytosine $(2)^{28}$ were reacted with

Scheme 1. Synthesis of Alkyne and Azide Nucleosides ${ }^{a}$

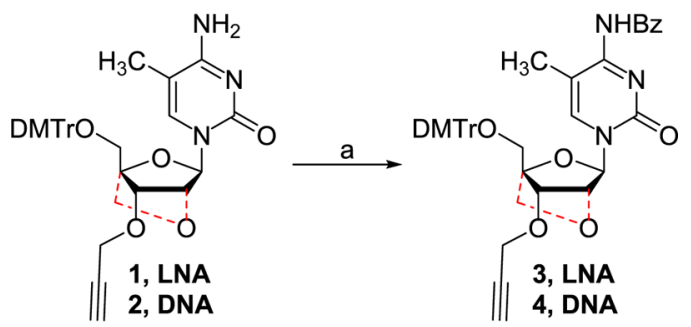

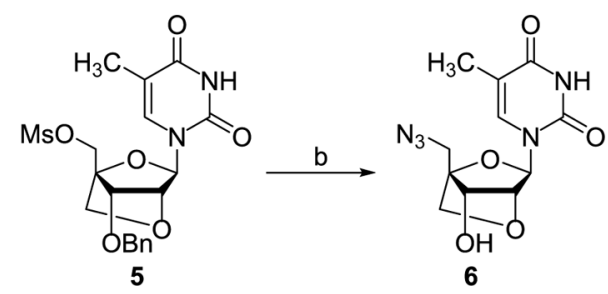

${ }^{a}$ Reagents and conditions: (a) $\mathrm{Bz}_{2} \mathrm{O}$, dimethylformamide (DMF): 3 (86\%), 4 (92\%); (b) (i) $\mathrm{Pd}(\mathrm{OH})_{2} / \mathrm{C}, \mathrm{MeOH}$, (ii) $\mathrm{NaN}_{3}, \mathrm{DMF}, 64 \%$ over two steps. benzoic anhydride to obtain protected nucleosides 3 and 4 in yields of 86 and $92 \%$, respectively. 5'-Azido-LNA thymidine (6) was obtained from protected nucleoside $5^{29}$ by removing the $3^{\prime}$-O-benzyl group followed by nucleophilic displacement of $5^{\prime}$ $O$-mesylate with azide. $5^{\prime}$-Azidothymidine (7, Scheme 2$)$ was prepared following a literature procedure. ${ }^{30}$

Dinucleosides 8-11, which contain the triazole linkage with and without LNA, were prepared in good yields (79-87\%) by $\mathrm{Cu}(\mathrm{I})$ catalyzed alkyne azide cycloaddition reaction ${ }^{31,32}$ between nucleosides 3, 4, 6, and 7 (Scheme 2). 3'-OPhosphitylation of 8-11 gave phosphoramidites $\mathbf{1 2 - 1 5}$ as suitable building blocks for incorporating monomers $\mathbf{W}-\mathbf{Z}$, respectively, into DNA via solid-phase DNA synthesis. For introducing monomers $\mathbf{W}-\mathbf{Z}$ at the $3^{\prime}$-end of ONs, dinucleosides 8-11 were loaded onto an activated amino-SynBase resin (16) using $N$-ethyl- $N^{\prime}$-(3-dimethylaminopropyl)carbodiimide hydrochloride (EDC) as the coupling reagent.

Hybridization Studies. Hybridization to Complementary RNA Targets. Having dinucleoside phosphoramidites in hand allowed multiple incorporations of the modified monomers internally and at the termini of ONs. Hence, phosphoramidites 12-15 were used to introduce monomers $\mathbf{W}-\mathrm{Z}$, respectively, into chosen $\mathrm{ON}$ sequences (Table 1). Six sequences were prepared: ON1-ON2 with modified monomers at $3^{\prime}$ - or $5^{\prime}$ end, ON3-ON4 bearing modified monomers in the middle region, ON5 containing two modifications in the middle, and ON6 incorporating four modified monomers (at the ends and in the middle). The modified ONs were then mixed with the complementary RNA sequences in a $10 \mathrm{mM}$ phosphate buffer containing $200 \mathrm{mM} \mathrm{NaCl}$ at $\mathrm{pH} 7.0$ and the melting temperatures $\left(T_{\mathrm{m}}\right)$ of the resulting duplexes were determined from the UV melting curves (Figure 2).

In accordance with the literature, duplexes formed between triazole-linked DNA and fully complementary RNA strands were less stable than the unmodifed DNA/RNA duplex (compare monomer $\mathbf{W}$ with $\mathbf{U}$ ). However, the drop in $T_{\mathrm{m}}$ caused by the triazole linkage was fully compensated for by either the introduction of LNA on the $3^{\prime}$-side (monomer $\mathbf{X}$ ) or 
Scheme 2. Synthesis of Triazole-Linked Dinucleoside Building Blocks ${ }^{a}$

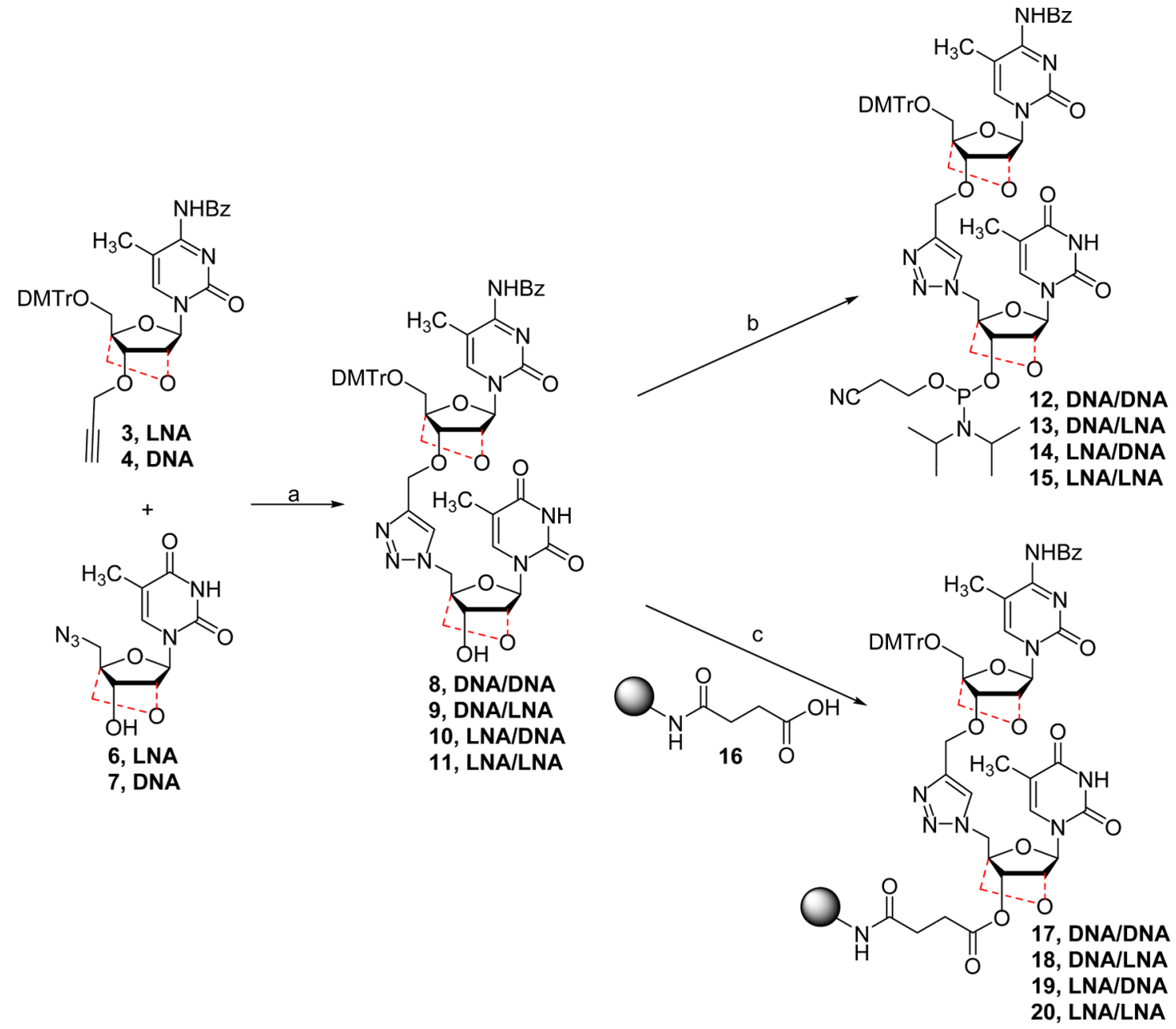

${ }^{a}$ Reagents and conditions: (a) $\mathrm{CuSO}_{4}, \mathrm{Na}$ ascorbate, tetrahydrofuran (THF)/t- $\mathrm{BuOH} / \mathrm{H}_{2} \mathrm{O}(3: 1: 1)$, pyridine, room temperature (rt), 8 (80\%), 9 (82\%), 10 (87\%), 11 (79\%); (b) 2-cyanoethyl $N, N$-diisopropylchlorophosphoramidite, $N, N$-diisopropylethylamine $\left(\mathrm{DIPEA}^{2}, \mathrm{CH}_{2} \mathrm{Cl}_{2}, \mathrm{rt}, 12(50 \%)\right.$, 13 (62\%), 14 (76\%), 15 (73\%), (c) $N$-ethyl- $N^{\prime}$-(3-dimethylaminopropyl)carbodiimide hydrochloride (EDC), 4-dimethylaminopyridine (DMAP), $\mathrm{Et}_{3} \mathrm{~N}$, pyridine, 17 (28 $\mu \mathrm{mol} / \mathrm{g}$ loading), 18 (26 $\mu \mathrm{mol} / \mathrm{g}$ loading), 19 (29 $\mu \mathrm{mol} / \mathrm{g}$ loading), and 20 (28 $\mu \mathrm{mol} / \mathrm{g}$ loading).

Table 1. Thermal Melting $\left(T_{\mathrm{m}}\right)$ Data for the DNA/RNA Duplexes

\begin{tabular}{|c|c|c|c|c|c|c|c|}
\hline \multirow[b]{2}{*}{ ON } & \multirow[b]{2}{*}{ ON sequence $\left(5^{\prime}-3^{\prime}\right)$} & \multirow[b]{2}{*}{$B={ }^{\mathrm{Me}} \mathrm{CpT}(\mathrm{U})$} & \multirow[b]{2}{*}{${ }^{\mathrm{Me}} \mathrm{C}^{\mathrm{L}} \mathrm{pT}^{\mathrm{L}}(\mathrm{V})$} & \multicolumn{4}{|c|}{$T_{\mathrm{m}}{ }^{a}\left(\Delta T_{\mathrm{m}}{ }^{b}\right)$} \\
\hline & & & & ${ }^{\mathrm{Me}} \mathrm{CtT}(\mathrm{W})$ & ${ }^{\mathrm{Me}} \mathrm{CtT}^{\mathrm{L}}(\mathrm{X})$ & ${ }^{\mathrm{Me}} \mathrm{C}^{\mathrm{L}} \mathrm{tT}(\mathrm{Y})$ & ${ }^{\mathrm{Me}} \mathrm{C}^{\mathrm{L}} \mathrm{T}^{\mathrm{L}}(\mathrm{Z})$ \\
\hline ON1 & 5'-CTC ACT ATC TGB & 54.8 & nd & $53.7(-1.1)$ & $54.6(-0.2)$ & $54.7(-0.1)$ & $55.0(+0.2)$ \\
\hline ON2 & 5'-BCA CTA TCT GCT & 54.0 & nd & $51.5(-2.5)$ & $55.7(+1.7)$ & $50.7(-3.3)$ & $54.8(+0.8)$ \\
\hline ON3 & 5'-CTC АВA ТCT GCT & 55.1 & $66.0(+10.9)$ & $49.6(-5.5)$ & $57.1(+2.0)$ & $49.8(-5.3)$ & $58.1(+3.0)$ \\
\hline ON4 & 5'-CTC АСТ АТВ GCT & 54.4 & nd & $49.4(-5.0)$ & $55.0(+0.6)$ & $49.2(-5.2)$ & $56.9(+2.5)$ \\
\hline ON5 & 5'-CTC ABA TBG СТ & 55.7 & nd & $43.7(-12.0)$ & $57.0(+1.3)$ & $44.1(-11.6)$ & $58.9(+3.2)$ \\
\hline ON6 & 5'-BCA BAT BGB & 56.7 & $>75$ & $39.4(-17.3)$ & $57.8(+1.1)$ & $38.3(-18.4)$ & $62.3(+5.6)$ \\
\hline
\end{tabular}

${ }^{a}$ Melting temperatures $\left(T_{\mathrm{m}}\right)$ were obtained from the maxima of the first derivatives of the melting curves $\left(A_{260}\right.$ vs temperature $)$ recorded in a buffer containing $10 \mathrm{mM}$ phosphate and $200 \mathrm{mM} \mathrm{NaCl}$ at $\mathrm{pH} 7.0$ using $3.0 \mu \mathrm{M}$ concentrations of each strand. ${ }^{b} \Delta T_{\mathrm{m}}=$ change in $T_{\mathrm{m}}$ for a modified duplex relative to the unmodified duplex. RNA target: $5^{\prime}$-AGC AGA UAG UGA G. nd = not determined. $\mathrm{p}=$ phosphodiester backbone. ${ }^{\mathrm{L}}=\mathrm{LNA}^{\mathrm{m}}$ nucleotide. $\mathrm{t}=$ triazole backbone.

on both sides of the linkage (monomer $\mathbf{Z}$ ). This observation is in full agreement with our previous study. ${ }^{16}$ Furthermore, the binding affinity of ONs carrying the modified monomers (W$\mathrm{Z}$ ) at the $3^{\prime}$-end (ON1W-ON1Z) was comparable to that of the unmodified $\mathrm{ON}(\mathrm{ON} 1 \mathrm{U})$, suggesting that all the monomers are well tolerated at this position. ONs bearing monomers $\mathbf{W}$ or $\mathbf{Y}$ at the $5^{\prime}$-end bind to their RNA targets with a slightly lower affinity than the unmodified DNA strand (compare ON2U with $\mathrm{ON} 2 \mathrm{~W}$ and $\mathrm{ON} 2 \mathrm{Y}, \Delta T_{\mathrm{m}}$ of -2.5 and $-3.3{ }^{\circ} \mathrm{C}$, respectively). In contrast, monomers $\mathbf{X}$ and $\mathbf{Z}$ with $\Delta T_{\mathrm{m}}$ of +1.7 and $+0.8{ }^{\circ} \mathrm{C}$ (compare $\mathrm{ON} 2 \mathrm{U}$ with $\mathrm{ON} 2 \mathrm{X}$ and $\mathrm{ON} 2 \mathrm{Z}$ ), respectively, induced a slight increase in binding affinity. A larger drop in thermal stability was observed with incorporation of either $\mathbf{W}$ or $\mathbf{Y}$ at the center of modified duplexes $\left(\Delta T_{\mathrm{m}} \mathrm{s}\right.$ in the range of 


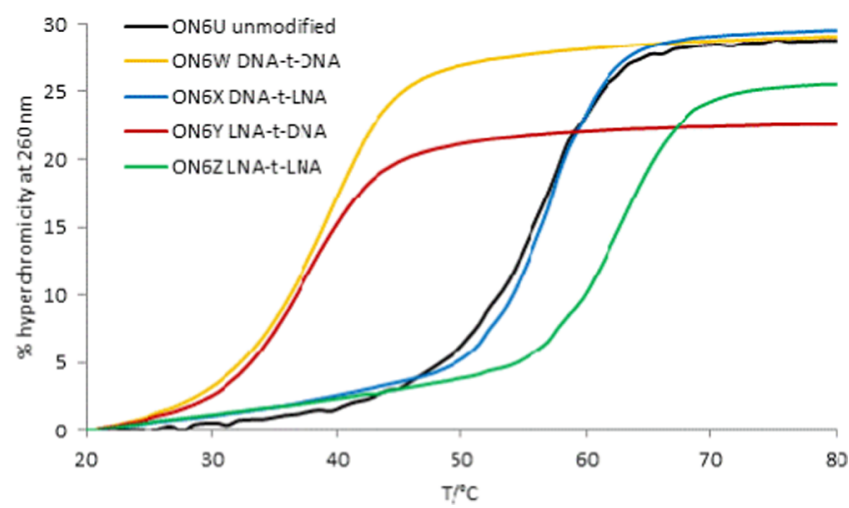

Figure 2. Representative UV melting curves for ON6 containing four triazole linkages (where $-\mathrm{t}-=$ triazole). These are the most heavily modified of all the oligonucleotides in Table 1. Additional melting curves are given in the SI (Figure S1). DNA/RNA hybrid duplexes containing four triazoles with no LNA or four triazoles with LNA on the $5^{\prime}$-side are significantly less stable than the unmodified duplex, whereas duplexes containing LNA on $3^{\prime}$-side of the triazole linkages displayed thermal stability comparable to unmodified duplex. Importantly, duplexes with LNA on both the $3^{\prime}$ - and $5^{\prime}$-side of the linkages were the most stable. $Y$-axis (\% hyperchromicity) was calculated as follows: $\left[\left(A_{260}\right.\right.$ at $T{ }^{\circ} \mathrm{C}-A_{260}$ at $\left.20{ }^{\circ} \mathrm{C}\right) / A_{260}$ at $\left.20{ }^{\circ} \mathrm{C}\right] \mathrm{x}$ 100.

-5.0 to $-5.5{ }^{\circ} \mathrm{C}$, ON3W, ON4W, ON3Y, and ON4Y). In contrast, one incorporation of monomers $\mathbf{X}$ or $\mathbf{Z}$ increased the thermal stability $\left(\Delta T_{\mathrm{m}}\right.$ of +0.6 to $+3.0{ }^{\circ} \mathrm{C}, \mathrm{ON} 3 \mathrm{X}, \mathrm{ON} 4 \mathrm{X}$, $\mathrm{ON} 3 \mathrm{Z}$, and $\mathrm{ON} 4 \mathrm{Z}$ ), with monomer $\mathrm{Z}$ being more effective than monomer $\mathbf{X}$ (compare ON3X with ON3Z and ON4X with $\mathrm{ON} 4 \mathrm{Z}$ ). Indeed, monomer $\mathbf{Z}$ with LNA sugars on both sides of the triazole linkage induced an increase of $3.0^{\circ} \mathrm{C}$ (ON3Z) in $T_{\mathrm{m}}$, which is the largest increase in this series for a single modification. Importantly, the thermal stability of a duplex with four incorporations of monomer $\mathbf{Z}$ was significantly higher than that of the unmodifed duplex (compare ON6U with ON6Z, $\Delta T_{\mathrm{m}}=+5.6^{\circ} \mathrm{C}$ ), and for monomer $\mathrm{X}$ (with LNA on the $3^{\prime}$-side of the triazole), a small increase in thermal stability was observed (compare ON6U with ON6X, $\Delta T_{\mathrm{m}}=$ $+1.1{ }^{\circ} \mathrm{C}$ ). In contrast, the modified duplexes carrying four incorporations of monomer $\mathbf{W}$ (triazole linkage without LNA) or Y (LNA on $5^{\prime}$-side of the triazole linkage) were strikingly less stable than the unmodified duplex (compare ON6W or ON6Y with ON6U, $\Delta T_{\mathrm{m}}=-17.3$ and $-18.4^{\circ} \mathrm{C}$, respectively).

Hybridization to Mismatched RNA Targets. To avoid "off target" effects that can lead to the inhibition of a wrong mRNA, ASOs must be able to differentiate between matched and mismatched RNA targets. ON3 with a backbone modification at the center was chosen to assess the binding specificity of the modified monomers. The nucleotides opposite to ${ }^{\mathrm{Me}} \mathrm{C}$ or $\mathrm{T}$ on either side of the triazole linkage were changed, and the $T_{\mathrm{m}}$ differences between matched and mismatched duplexes were recorded (Table 2). In general, monomers $\mathbf{W}-\mathbf{Z}$ discriminated between a matched and a single-mismatch target with the efficiency similar to that of the unmodified base (U). Monomer W (triazole linkage without LNA) was least effective in sensing a mismatched nucleotide. Monomer V (LNA without a triazole linkage) gave a good mismatch discrimination in all the cases (e.g., compare ON3U with ON3V), which is in agreement with the literature. ${ }^{25}$ Monomer X, with LNA on the $3^{\prime}$-side of the triazole linkage showed the greatest discrimination for a mismatched nucleotide on the $3^{\prime}$-side of the triazole linkage. However, marginally inferior discrimination was observed for monomer $\mathbf{Y}$, which carries LNA on the 5 '-side of the linkage. Monomer Z, which has LNA on both sides of the triazole linkage showed improved discrimination for the mismatch nucleotide on the $3^{\prime}$-side of the triazole linkage ( $\mathrm{T}-\mathrm{C}$ and $\mathrm{T}-$ $\mathrm{G}$ mismatch). Monomer $\mathrm{Z}$ discriminated against a mismatch guanine base ( $\mathrm{T}-\mathrm{G}$ mismatch) with greater efficiency than that of the unmodified ON (compare ON3U with ON3Z). The T$\mathrm{G}$ mismatch discrimination for $\mathbf{Z}$ was also noticeably superior to that observed for monomers $\mathbf{X}$ or $\mathbf{V}$ (compare ON3Z with $\mathrm{ON} 3 \mathbf{X}$ or ON3V). The greater relative destabilization of the $\mathrm{T}-\mathrm{G}$ mismatch is significant, as this mismatch is generally quite stable. The ability to discriminate between mispaired nucleotides was then studied for ONs containing four incorporations of monomers $\mathbf{X}$ and $\mathbf{Z}$ (Table S2) and similar results were observed. Again, significant destabilization of duplexes containing a $\mathrm{T}-\mathrm{G}$ mismatch was observed (compare ON6Z with ON6U).

In summary, the combined hybridization data (Tables 1 and 2) indicate that LNA on the $3^{\prime}$-side of the triazole linkage maintains its beneficial effects on RNA binding affinity and specificity, but this is not true for LNA on the $5^{\prime}$-side of the triazole linkage. Our explanation for this behavior is that LNA

Table 2. Mismatch Data for ONs Containing Modified Monomer in the Center (ON3U-ON3Z)

\begin{tabular}{|c|c|c|c|c|c|c|c|}
\hline \multirow[b]{4}{*}{ ON code } & \multirow[b]{4}{*}{ ON sequence $\left(5^{\prime}-3^{\prime}\right)$} & \multicolumn{3}{|c|}{ mismatch data against ${ }^{\mathrm{Me}} \mathrm{C}$ ( $5^{\prime}$-side of the linkage) } & \multicolumn{3}{|c|}{$\begin{array}{l}\text { mismatch data against } \mathrm{T} \\
\text { (3'-side of the linkage) }\end{array}$} \\
\hline & & \multirow{3}{*}{$\begin{array}{c}T_{\mathrm{m}}{ }^{a} \\
\text { match } \\
{ }^{\mathrm{Me}} \mathrm{C}-\mathrm{G}\end{array}$} & \multirow{2}{*}{\multicolumn{2}{|c|}{$\frac{\Delta T_{\mathrm{m}}^{b}}{\text { mismatch }}$}} & \multirow{3}{*}{$\begin{array}{c}\frac{T_{\mathrm{m}}{ }^{a}}{\text { match }} \\
\mathrm{T}-\mathrm{A}\end{array}$} & \multirow{2}{*}{\multicolumn{2}{|c|}{$\frac{\Delta T_{\mathrm{m}}{ }^{b}}{\text { mismatch }}$}} \\
\hline & & & & & & & \\
\hline & & & ${ }^{\mathrm{Me}} \mathrm{C}-\mathrm{U}$ & ${ }^{\mathrm{Me}} \mathrm{C}-\mathrm{A}$ & & $\mathrm{T}-\mathrm{C}$ & $\mathrm{T}-\mathrm{G}$ \\
\hline ON3U & $5^{\prime}$-CTC A ${ }^{\mathrm{Me}} \mathrm{CpT}$ A TCT GCT & 55.1 & -17.7 & -16.1 & 55.1 & -12.3 & -3.4 \\
\hline ON3V & $5^{\prime}$-CTC A ${ }^{M e} C^{L} p T^{L}$ A TCT GCT & 66.0 & -18.1 & -17.2 & 66.0 & -12.9 & -4.6 \\
\hline ON3W & $5^{\prime}$-CTC A ${ }^{\mathrm{Me}} \mathrm{CtT}$ A TCT GCT & 49.6 & -17.0 & -15.2 & 49.6 & -10.7 & -2.1 \\
\hline ON3X & $5^{\prime}$-CTC A ${ }^{\mathrm{Me}} \mathrm{CtT}^{\mathrm{L}}$ A TCT GCT & 57.1 & -16.9 & -15.5 & 57.1 & -13.8 & -5.6 \\
\hline ON3Y & $5^{\prime}$-CTC A ${ }^{\mathrm{Me}} \mathrm{C}^{\mathrm{L}} \mathrm{tT}$ A TCT GCT & 49.8 & -17.1 & -16.3 & 49.8 & -11.3 & -4.2 \\
\hline ON3Z & $5^{\prime}$-CTC A ${ }^{\mathrm{Me}} \mathrm{C}^{\mathrm{L}} \mathrm{tT}^{\mathrm{L}}$ A TCT GCT & 58.1 & -17.3 & -16.8 & 58.1 & -15.2 & -6.8 \\
\hline
\end{tabular}

${ }^{a}$ Melting temperatures $\left(T_{\mathrm{m}}\right)$ were obtained from the maxima of the first derivatives of the melting curves $\left(A_{260}\right.$ vs temperature) recorded in a buffer containing $10 \mathrm{mM}$ phosphate and $200 \mathrm{mM} \mathrm{NaCl}$ at $\mathrm{pH} 7.0$ using $3.0 \mu \mathrm{M}$ concentrations of each strand. ${ }^{b} \Delta T_{\mathrm{m}}=$ change in $T_{\mathrm{m}}$ for a mismatch duplex relative to the corresponding matched duplex. $\mathrm{p}=$ phosphodiester backbone. ${ }^{\mathrm{L}}=$ LNA nucleotide. $\mathrm{t}=$ triazole backbone. Matched RNA target: $5^{\prime}$ AGCAGAUAGUGAG. Mismatch RNA targets: 5'-AGCAGAUAUUGAG ( ${ }^{\mathrm{Me}} \mathrm{C}-\mathrm{U}$ mismatch), $5^{\prime}$-AGCAGAUAAUGAG $\left({ }^{\mathrm{Me}} \mathrm{C}-\mathrm{A}\right.$ mismatch), $5^{\prime}$ AGCAGAUCGUGAG (T-C mismatch), 5'-AGCAGAUGGUGAG ( $\mathrm{T}-\mathrm{G}$ mismatch). 
Table 3. Thermal Melting $\left(T_{\mathrm{m}}\right)$ Data for the DNA/DNA Duplexes

\begin{tabular}{|c|c|c|c|c|c|c|}
\hline \multirow[b]{2}{*}{ ON code } & \multirow[b]{2}{*}{ ON sequence $\left(5^{\prime}-3^{\prime}\right)$} & \multirow[b]{2}{*}{$\mathrm{B}={ }^{\mathrm{Me}} \mathrm{CpT}(\mathrm{U})$} & \multicolumn{4}{|c|}{$T_{\mathrm{m}}^{a}\left(\Delta T_{\mathrm{m}}^{b}\right)$} \\
\hline & & & ${ }^{\mathrm{Me}} \mathrm{CtT}(\mathrm{W})$ & ${ }^{\mathrm{Me}} \mathrm{CtT}^{\mathrm{L}}(\mathrm{X})$ & ${ }^{\mathrm{Me}} \mathrm{C}^{\mathrm{L}} \mathrm{tT}(\mathrm{Y})$ & ${ }^{\mathrm{Me}} \mathrm{C}^{\mathrm{L}} \mathrm{tT}^{\mathrm{L}}(\mathrm{Z})$ \\
\hline ON1 & 5'-CTC ACT ATC TGB & 54.5 & $53.7(-0.8)$ & $52.8(-1.7)$ & $53.1(-1.4)$ & $53.5(-1.0)$ \\
\hline ON2 & 5'-BCA CTA TCT GCT & 53.8 & $50.9(-2.9)$ & $49.1(-4.7)$ & $49.4(-4.4)$ & $49.6(-4.2)$ \\
\hline ON3 & 5'-CTC АBA TCT GCT & 54.9 & $47.5(-7.4)$ & $51.4(-3.5)$ & $44.4(-10.5)$ & $53.4(-1.5)$ \\
\hline ON4 & 5'-CTC ACT АTB GCT & 54.4 & $49.7(-4.7)$ & $51.0(-3.4)$ & $45.0(-9.4)$ & $52.1(-2.3)$ \\
\hline ON5 & 5'-CTC ABA TBG CT & 55.9 & $41.0(-14.9)$ & $48.6(-7.3)$ & $34.2(-21.7)$ & $51.4(-4.5)$ \\
\hline ON6 & 5'-BCA BAT BGB & 58.0 & $37.6(-20.4)$ & $45.8(-12.2)$ & $<-30.0$ & $48.3(-9.7)$ \\
\hline
\end{tabular}

${ }^{a}$ Melting temperatures $\left(T_{\mathrm{m}}\right)$ were obtained from the maxima of the first derivatives of the melting curves $\left(A_{260}\right.$ vs temperature $)$ recorded in a buffer containing $10 \mathrm{mM}$ phosphate and $200 \mathrm{mM} \mathrm{NaCl}$ at pH 7.0 using $3.0 \mu \mathrm{M}$ concentrations of each strand. ${ }^{b} \Delta T_{\mathrm{m}}=$ change in $T_{\mathrm{m}}$ for a modified duplex relative to the unmodified duplex 5'-CTC ACT ATC TG ${ }^{\mathrm{Me}}$ CT. $\mathrm{p}=$ phosphodiester backbone. ${ }^{\mathrm{L}}=\mathrm{LNA}$ nucleotide. $\mathrm{t}=$ triazole backbone.

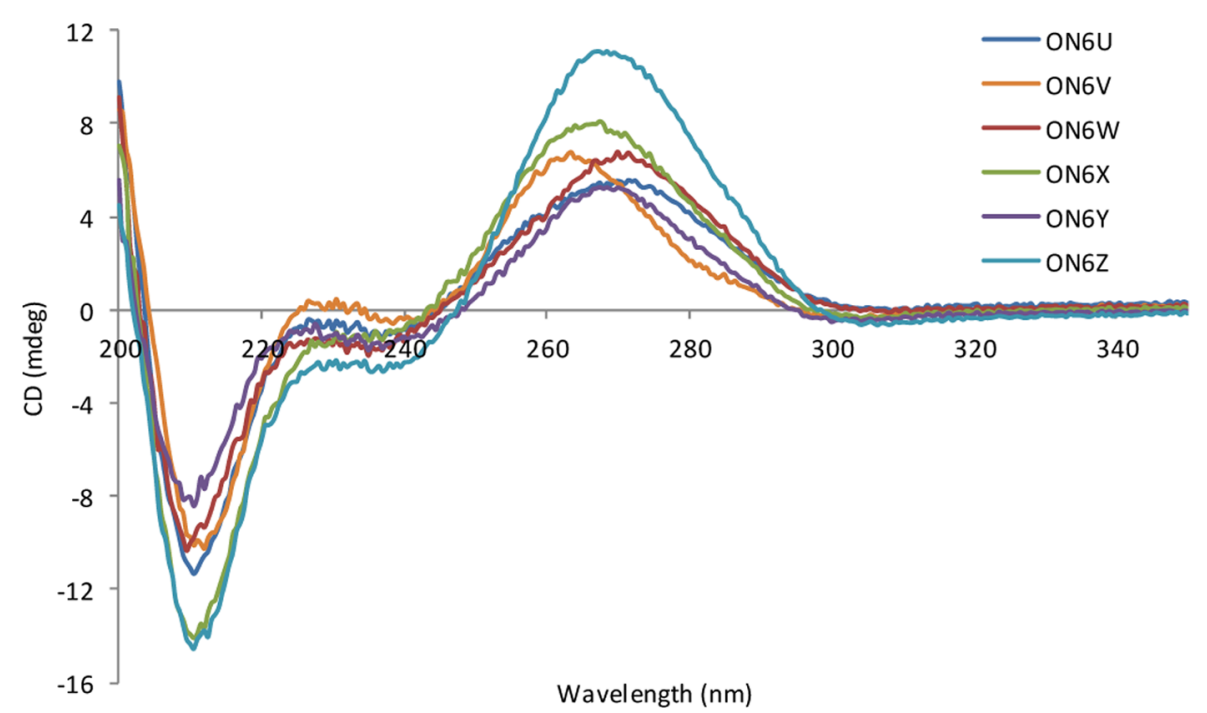

Figure 3. CD spectra of duplexes formed between ON6U-ON6Z and complementary RNA. ON6: 5'-BCA BAT BGB (ON6U, B = ${ }^{\text {Me }}$ CpT; ON6V, $\mathrm{B}={ }^{\mathrm{Me}} \mathrm{C}^{\mathrm{L}} \mathrm{pT}^{\mathrm{L}}$; ON6W, B $={ }^{\mathrm{Me}} \mathrm{CtT}$; ON6X, B $={ }^{\mathrm{Me}} \mathrm{CtT}^{\mathrm{L}}$; ON6Y, B $\left.={ }^{\mathrm{Me}} \mathrm{C}^{\mathrm{L}} \mathrm{tT} ; \mathrm{ON6Z}, \mathrm{B}={ }^{\mathrm{Me}} \mathrm{C}^{\mathrm{L}} \mathrm{tT}^{\mathrm{L}}\right)$.

on the $3^{\prime}$-side of the triazole is attached to a natural phosphodiester group, but when present on the $5^{\prime}$-side of the triazole, the LNA sugar is attached to a more flexible triazole linkage. LNA stabilizes DNA/RNA duplexes by reducing phosphate backbone flexibility, ${ }^{24,33}$ which may not be possible when the LNA sugar is attached directly to the more flexible modified linkage and/or is close to an unstable mismatched base pair.

Hybridization to DNA Targets. Next, modified ONs were mixed with their DNA targets in a buffer containing $10 \mathrm{mM}$ phosphate and $200 \mathrm{mM} \mathrm{NaCl}$ at $\mathrm{pH} 7.0$ to give DNA/DNA duplexes and $T_{\mathrm{m}} \mathrm{s}$ were recorded. These were then compared with the $T_{\mathrm{m}}$ of the unmodified DNA/DNA duplex and differences $\left(\Delta T_{\mathrm{m}} \mathrm{s}\right)$ were determined (Table 3$)$. In all the cases, the thermal stabilities of the modified duplexes were lower than those of the unmodified duplexes (negative $\Delta T_{\mathrm{m}} \mathrm{s}$ ). However, as observed for DNA/RNA duplexes, modifications were better tolerated at the $3^{\prime}$-end relative to other positions $\left(\Delta T_{\mathrm{m}}\right.$ s only in the range of -0.8 to $-1.7^{\circ} \mathrm{C}$, compare ON1WON1Z with ON1U). A large drop in $T_{\mathrm{m}}$ was observed for monomer $\mathbf{W}$ at internal positions, which is consistent with the literature (compare ON3W and ON4W with ON3U). ${ }^{19,20}$ Surprisingly, monomers $\mathbf{X}$ and $\mathbf{Z}$ were better accommodated at the center of the duplex compared to the $5^{\prime}$-end, and the thermal stability of the modified duplex incorporating monomer $\mathbf{Z}$ in the center was similar to that of unmodified duplex (compare ON3Z with ON3U, drop of only $1.5^{\circ} \mathrm{C}$ ). As with the DNA/RNA duplexes, monomer $\mathrm{Z}$ gave the highest melting temperatures for all DNA/DNA duplexes. It is not surprising that the triazole-LNA combination stabilizes the DNA/RNA duplexes to a greater degree than it does the DNA/ DNA duplexes. This is because the LNA sugar exists in the C3'endo conformation, which occurs in A-type helices (DNA/ RNA and RNA/RNA) but is disfavored in DNA/DNA duplexes in solution. ${ }^{24,34}$

Circular Dichroism (CD) Spectroscopy. CD spectra of the modified duplexes obtained by mixing ON6 (ON6UON6Z, Table 1) with RNA targets were recorded in a buffer containing $10 \mathrm{mM}$ phosphate and $200 \mathrm{mM} \mathrm{NaCl}$ at $\mathrm{pH} 7.0$ and the results are shown in Figure 3. Neither LNA nor the triazole linkage significantly alters the global conformation of the DNA/ RNA duplexes (compare ON6V-ON6Z with ON6U). However, subtle shifts in CD maxima near $272 \mathrm{~nm}$ were observed. For instance, the $\mathrm{CD}$ spectrum of the duplex containing LNA but no triazole linkage (monomer V) displayed a maximum at $263 \mathrm{~nm}$ (a hypsochromic shift of 9 $\mathrm{nm})$. For duplexes containing LNA on the $3^{\prime}$-side or both sides of the triazole linkage (monomers $\mathbf{X}$ and $\mathbf{Z}$ ), the $\mathrm{CD}$ maxima were observed at around $267 \mathrm{~nm}$ (a hypsochromic shift of 5 $\mathrm{nm}$ ), whereas monomer $\mathbf{W}$ (triazole linkage but no LNA) or monomer Y (LNA on the 5 -side of the linkage) did not induce a noticeable shift in their CD maxima. Interpretation of these shifts in terms of DNA conformation is not straightforward, but the changes are modest, and overall geometry of the duplexes 

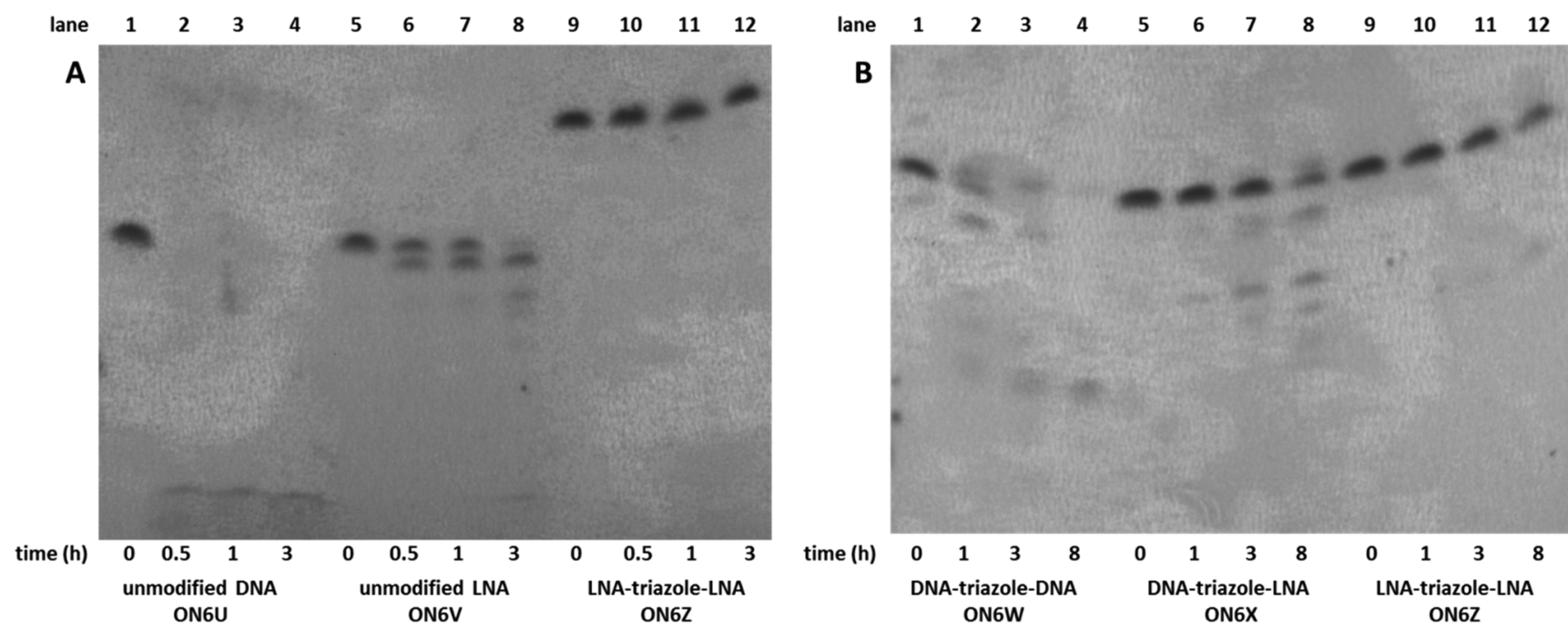

Figure 4. Denaturing polyacrylamide gel electrophoresis (PAGE) analysis of ON6U-ON6Z after digestion with phosphodiesterase 1 from $C$. adamanteus, snake venom. This shows that the introduction of LNA next to the triazole improves stability against nucleases. Digestions were performed using snake venom in $50 \mathrm{mM}$ Tris buffer containing $10 \mathrm{mM} \mathrm{MgCl}_{2}$ at $\mathrm{pH}=9.0$. (A) Comparison of nuclease stability of ON6U, ON6V, and ON6Z. (B) Comparison of nuclease stability of ON6W, ON6X, and ON6Z.

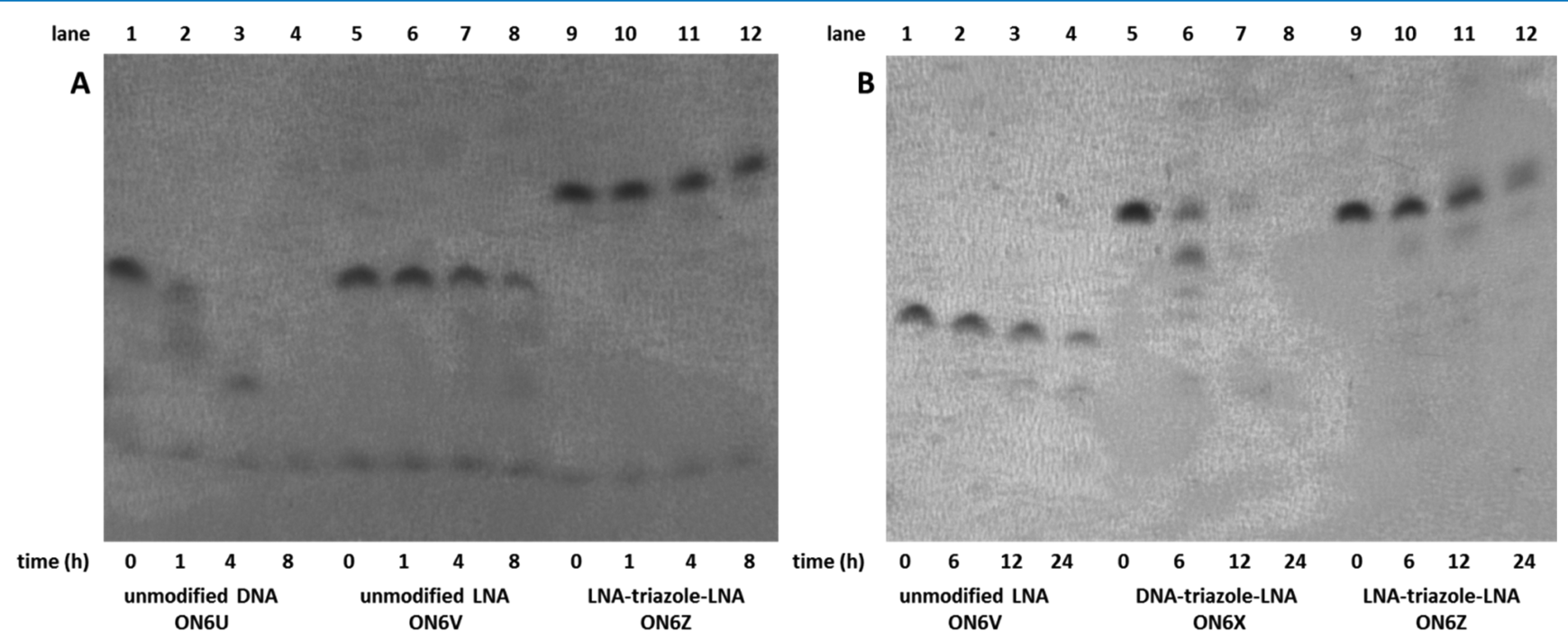

Figure 5. Denaturing PAGE analysis of ON6U-ON6Z after digestion by FBS in DPBS supplemented with 50\% FBS. (A) Comparison of enzymatic stability of ON6U, ON6V, and ON6Z. (B) Comparison of enzymatic stability of ON6V, ON6X, and ON6Z.

carrying LNA-triazole modifications is likely to be similar to the unmodified DNA/RNA duplex. Nevertheless, an interesting and significant trend emerges. The hypsochromic shifts observed for LNA-containing duplexes in Figure 3 are in line with previously reported data $^{34}$ and could be attributed to enhanced A-form-geometry due to the restricted conformational mobility of LNA. Assuming that flexible triazole linkages partially (triazole-3'-LNA) or almost totally (5'-LNAtriazole) eliminate beneficial LNA-driven A-form conformational changes, the extent of the hypsochromic shift should decrease in the following order: ON6V (uncompensated LNA effects) > ON6X and ON6Z (partially compensated LNA effects) > ON6Y (almost totally compensated LNA effect) > ON6W and ON6U (no LNA, zero shift). The relative magnitudes of these hypsochromic shifts are also proportional to differences in melting temperatures, precisely as would be expected.
Enzymatic Stability of t-LNAs. Oligonucleotides ON6UON6Z (Table 1) were incubated with phosphodiesterase 1 from Crotalus adamanteus, snake venom ( $3^{\prime}$-exonuclease), in 50 $\mathrm{mM}$ Tris buffer containing $10 \mathrm{mM} \mathrm{MgCl}_{2}$ at $\mathrm{pH}=9.0$ to determine their resistance to nucleolytic degradation. Aliquots were taken over different time intervals and analyzed by $20 \%$ polyacrylamide gel electrophoresis (PAGE) (Figure 4). Figure $4 \mathrm{~A}$ shows a direct comparison between the unmodified DNA strand (ON6U), an ON containing eight LNAs but no triazole linkage (ON6V) and an $\mathrm{ON}$ with four incorporations of monomer $\mathbf{Z}$ (ON6Z, best candidate from thermal melting data). It is evident that multiple incorporations of monomer $\mathbf{Z}$ render the modified $\mathrm{ON}$ remarkably resistant to degradation by snake venom. After $3 \mathrm{~h}, \mathrm{ON} 6 \mathrm{Z}$ is clearly visible, whereas both ON6U and ON6V are fully degraded. Next, the enzymatic stability of ON6W, ON6X, and ON6Z was compared (Figure 4B). This shows that the introduction of LNA next to the triazole improves stability against this nuclease, with $\mathrm{ON} 6 \mathrm{Z}$ 
being more stable than $\mathrm{ON} 6 \mathbf{X}$, which, in turn, is more stable than ON6W. It is surprising that this $3^{\prime}$-exonuclease cleaves ON6W so readily, as this must require the removal of an entire triazole-linked dinucleotide from the 3 '-end of the oligonucleotide (by digestion of the closest available unmodified phosphodiester linkage). In contrast, the extreme stability of ON6Z to snake venom phosphodiesterase shows that there is a synergistic effect between LNA and triazole, justifying the modified DNA linkage design on which this study is based.

Next, the stability of ON6V-ON6Z in fetal bovine serum (FBS) was tested and compared with that of the unmodified ON6U (Figures 5 and S2). FBS contains predominantly endonucleases, so it has different enzymatic DNA degrading activity to snake venom, which is a $3^{\prime}$-exonuclease. FBS was chosen for this study because it will simulate the extracellular conditions to which a therapeutic oligonucleotide would be exposed. ONs were incubated with FBS (50\%) in Dulbecco's phosphate-buffered saline (DPBS). Unmodified DNA (ON6U) was completely digested within $4 \mathrm{~h}$ of incubation, whereas both ON6Z and ON6V were stable for up to $8 \mathrm{~h}$ (Figure 5A). The observation that LNA enhances the resistance of triazole-linked ONs against nucleolytic degradation in serum was further supported by the fact that ON6Z (LNA on both sides of the triazole linkage) is more stable (visible up to $24 \mathrm{~h}$ ) than the ON6X (LNA only on 3'-side of the linkage), and the observation that ON6W containing triazole linkages without LNA is less stable (Figure S2). Interestingly, ON6V (eight LNAs) was more stable in serum than ON6X (four triazole linkages and four LNAs), whereas ON6V and ON6Z with eight LNA sugars have similar stability (both stable up to $24 \mathrm{~h}$ ). This confirms that LNA is a significant contributor to enzymatic stability in serum. The triazole linkage (monomer W) is a mimic of phosphodiester linkage and is biocompatible, ${ }^{35}$ so it might be able to bind to serum endonucleases in a fashion similar to unmodified linkage and allow adjacent phosphodiesters to be cleaved (ON6X has eight unmodified phosphodiester linkages). In contrast, LNA has a locked sugar ( 3 '-endo), which could inhibit the binding of nucleases to the single-stranded ON. To summarize, t-LNAs with LNA on either side of the triazole linkage have the highest stability against nucleolytic degradation, in addition to the strongest affinity for RNA targets.

\section{CONCLUSIONS}

The efficient synthesis of dinucleoside phosphoramidites containing a triazole linkage and LNA sugars has been achieved. Access to these dinucleoside phosphoramidites allowed the incorporation of the triazole linkage flanked by LNA at multiple positions in oligonucleotides, including the central region and the $3^{\prime}$ - and $5^{\prime}$-ends. This was not feasible with our earlier ligation-based strategy where short ONs were joined together using click chemistry. There are several examples of a short triazole linkage being introduced into oligonucleotides via phosphoramidite monomers, but in all the cases, the duplexes were greatly destabilized. ${ }^{21-23}$ There is also one report of this short triazole being combined with LNA and added to oligonucleotides by phophoramidite chemistry, but unlike our triazole, this particular linkage was strongly duplexdestabilizing despite the presence of LNA. ${ }^{15}$ Another study described the synthesis of triazole-linked DNA by phosphoramidite chemistry using an inverted version of the triazole unit employed in this study, and this linkage slightly destabilized double-stranded DNA. ${ }^{17}$ In contrast, in this study, we have shown that oligonucleotides ( $\mathrm{t}$-LNAs) that contain the triazole linkage in Figure 1 flanked by LNA on the $3^{\prime}$ - or both sides (monomers $\mathbf{X}$ and $\mathbf{Z}$, respectively) bind to their RNA targets with higher affinity and specificity than the equivalent unmodified ONs. In addition, t-LNAs containing multiple incorporations of monomers $\mathbf{X}$ and $\mathbf{Z}$ are highly resistant to nuclease degradation, and there is a synergistic effect on enzymatic stability from the combined triazole-LNA linkages. Further biochemical and biological studies are required, but so far the indications are that $\mathrm{t}$-LNAs constitute a promising class of oligonucleotides with potential antisense and splicemodulating applications. ${ }^{36}$ They display extreme stability to enzymatic degradation, high RNA-binding affinity and RNA target specificity, and reduced anionic charge. The effects on cellular uptake of reducing the overall anionic nature of oligonucleotides by incorporation of LNA-triazole linkages will be interesting to study, given that oligonucleotide delivery is a major issue in therapeutic applications. The dinucleotide phosphoramidite strategy described in this article also allows for the synthesis of LNA triazoles, which incorporate phosphorothioate linkages, which might further enhance cell uptake. It is also possible that such oligonucleotide analogues will have different toxicological properties than LNA because it is not possible for any of the LNA-triazole dimers to be degraded into LNA nucleotides, so they cannot enter the mononucleotide triphosphate pool and therefore they cannot be incorporated into genomic DNA or RNA. The results presented here and previously ${ }^{16}$ suggest that, in addition to potential therapeutic applications, modified t-LNAs could find uses in imaging, diagnostics, and nontherapeutic siRNA applications.

\section{EXPERIMENTAL SECTION}

All the reagents were purchased from Sigma-Aldrich, Alfa Aesar, Fisher Scientific, or Link Technologies and used without further purification. Pyridine (from $\mathrm{KOH}$ ) and $\mathrm{POCl}_{3}$ were freshly distilled before use, and THF was obtained using the MBraun SPS Bench Top solvent purification system (SPS). All air/moisture-sensitive reactions were carried out under inert atmosphere (argon) in an oven-dried glassware. Reactions were monitored by thin-layer chromatography using Merck Kieselgel 60 F24 silica gel plates $(0.22 \mathrm{~mm}$ thickness, aluminum backed). The compounds were visualized by UV irradiation at 254/265 $\mathrm{nm}$ and by staining in $p$-anisaldehyde solution. Column chromatography was carried out under pressure using Biotage SNAP Ultra columns. The columns were primed with $\mathrm{CH}_{2} \mathrm{Cl}_{2}$ containing $1 \%$ pyridine before use for all DMTr-containing compounds. ${ }^{1} \mathrm{H}$ and ${ }^{13} \mathrm{C}$ spectra were measured on a Bruker AVII 500 spectrometer at 500 and $126 \mathrm{MHz}$, respectively. Chemical shifts are given in parts per million and were internally referenced to the appropriate residual solvent signal, all coupling constants $(J)$ are quoted in hertz $(\mathrm{Hz})$. Assignment of compounds was aided by correlated spectroscopy, heteronuclear single quantum coherence, heteronuclear multiple bond correlation, and distortionless enhancement by polarization transfer-135 experiments. The high-resolution mass spectra were measured on a Bruker 9.4 FT-ICR-MS mass spectrometer, and the samples were run in $\mathrm{MeOH}$.

$N_{6}$-Benzoyl-5'-O-(4,4'-dimethoxytrityl)-3'-O-propargyl-5-methyl-LNA Cytidine (3). To a solution of nucleoside $1^{16}(0.74 \mathrm{~g}, 1.21 \mathrm{mmol})$ in DMF $(5 \mathrm{~mL})$ was added benzoic anhydride $(0.41 \mathrm{~g}, 1.81 \mathrm{mmol})$. The reaction mixture was stirred at room temperature for $18 \mathrm{~h}$. The solvent was removed 
and the residue was taken up in EtOAc $(100 \mathrm{~mL})$, washed with sat. aqueous $\mathrm{NaHCO}_{3}(50 \mathrm{~mL})$, brine $(2 \times 50 \mathrm{~mL})$, dried $\left(\mathrm{Na}_{2} \mathrm{SO}_{4}\right)$, and concentrated. The crude mixture was purified using column chromatography (0-50\% EtOAc in hexane) to obtain $3(0.75 \mathrm{~g}, 86 \%)$ as a white foam. $R_{f}(0.4,40 \%$ EtOAc in hexane). ESI HRMS $m / z 712.2663([\mathrm{M}-\mathrm{H}])^{-}, \mathrm{C}_{42} \mathrm{H}_{38} \mathrm{O}_{8} \mathrm{~N}_{3}{ }^{-}$ calc. 712.2664. ${ }^{1} \mathrm{H}$ NMR (500 MHz, DMSO) $\delta 13.12(\mathrm{bs}, 1 \mathrm{H}$, $\mathrm{NH}), 8.18$ (m, 2H, Ph), 7.85 (s, 1H, H6), 7.61-7.58 (m, 1H, $\mathrm{Ph}), 7.51-7.47$ (m, 4H, DMTr, Ph), 7.37-7.33 (m, 6H, DMTr), 7.28-7.25 (m, 1H, DMTr), 6.95-6.93 (m, 4H, DMTr), 5.59 (s, 1H, H1' ), 4.68 (s, 1H, H2'), 4.39 (s, 1H, H3'), 4.35 (dd, $\left.J=16.0,2.4 \mathrm{~Hz}, 1 \mathrm{H}, \mathrm{CH}_{2} \mathrm{C} \equiv \mathrm{CH}\right), 4.29$ (dd, $J=16.0$, $\left.2.4 \mathrm{~Hz}, 1 \mathrm{H}, \mathrm{CH}_{2} \mathrm{C} \equiv \mathrm{CH}\right), 3.75-3.71\left(\mathrm{~m}, 7 \mathrm{H}, 2 \times \mathrm{OCH}_{3}\right.$, H5"), 3.74-3.72 (d, $\left.J=8.0 \mathrm{~Hz}, 1 \mathrm{H}, \mathrm{H} 5^{\prime \prime}\right), 3.55$ (t, $J=2.4 \mathrm{~Hz}$, $1 \mathrm{H}, \mathrm{C} \equiv \mathrm{CH}), 3.44\left(\mathrm{~d}, J=11.1 \mathrm{~Hz}, 1 \mathrm{H}, \mathrm{H} 5^{\prime}\right), 3.38$ (d, $J=11.1$ $\left.\mathrm{Hz}, 1 \mathrm{H}, \mathrm{H}^{\prime}\right), 1.81\left(\mathrm{~s}, 3 \mathrm{H}, \mathrm{CH}_{3}\right) .{ }^{13} \mathrm{C} \mathrm{NMR}(126 \mathrm{MHz}$, DMSO) $\delta 158.2,158.2$ (C4/DMTr), 144.5 (C2), 136.7 (C6), $135.2,134.9,132.5,129.8,129.3,128.3,128.0,127.7,126.9$, 113.4 (DMTr, Ph), 109.2 (C5), 87.1 (C4'), 86.9 (C1'), 85.9 (DMTr), $79.8(\mathrm{C} \equiv \underline{\mathrm{CH}}), 78.0(\underline{\mathrm{C}} \equiv \mathrm{CH}), 75.9\left(\mathrm{C}^{\prime}\right), 75.5$ (C3'), $71.7\left(\mathrm{C5}^{\prime \prime}\right), 57.9\left(\mathrm{CH}_{2}\right), 57.1\left(\mathrm{C5}^{\prime}\right), 55.1\left(2 \times \mathrm{OCH}_{3}\right)$, $13.5\left(\mathrm{CH}_{3}\right)$. A small impurity of ethyl acetate and $\mathrm{CH}_{2} \mathrm{Cl}_{2}$ as residual solvent was found. The compound was used as such in the next step.

$\mathrm{N}_{6}$-Benzoyl-5'-O-(4,4'-dimethoxytrityl)-3'-O-propargyl-5-methyl-2'-deoxycytidine (4). To a solution of nucleoside $2^{28}(1.20 \mathrm{~g}, 2.07 \mathrm{mmol})$ in $\operatorname{DMF}(5 \mathrm{~mL})$ was added benzoic anhydride $(0.93 \mathrm{~g}, 4.11 \mathrm{mmol})$. The reaction mixture was stirred at room temperature for $20 \mathrm{~h}$. The solvent was removed and residue was taken up in EtOAc $(100 \mathrm{~mL})$, washed with sat. aqueous $\mathrm{NaHCO}_{3}(50 \mathrm{~mL})$, brine $(2 \times 50 \mathrm{~mL})$, dried $\left(\mathrm{Na}_{2} \mathrm{SO}_{4}\right)$, and concentrated. The crude mixture was purified using column chromatography (0-50\% EtOAc in hexane) to obtain $4(1.30 \mathrm{~g}, 92 \%)$ as a white foam. $R_{f}(0.5,50 \%$ EtOAc in hexane). ESI HRMS $m / z 686.2856([\mathrm{M}+\mathrm{H}])^{+}, \mathrm{C}_{41} \mathrm{H}_{40} \mathrm{O}_{7} \mathrm{~N}_{3}^{+}$ calc. 686.2861. ${ }^{1} \mathrm{H}$ NMR (400 MHz, DMSO) $\delta 12.95$ (bs, $1 \mathrm{H}$, $\mathrm{NH}), 8.17(\mathrm{~m}, 2 \mathrm{H}, \mathrm{Ph}), 7.80$ (s, 1H, H6), 7.62-7.58 (m, 1H, $\mathrm{Ph}), 7.52-7.48(\mathrm{~m}, 2 \mathrm{H}, \mathrm{Ph}), 7.43-7.40(\mathrm{~m}, 2 \mathrm{H}, \mathrm{DMTr}), 7.35$ $(\mathrm{t}, J=7.6 \mathrm{~Hz}, 2 \mathrm{H}, \mathrm{DMTr}), 7.30-7.24(\mathrm{~m}, 5 \mathrm{H}, \mathrm{DMTr}), 6.93$ (d, $J=8.8 \mathrm{~Hz}, 4 \mathrm{H}, \mathrm{DMTr}), 6.15\left(\mathrm{t}, J=6.8 \mathrm{~Hz}, 1 \mathrm{H}, \mathrm{H1}^{\prime}\right), 4.52-$ $4.50\left(\mathrm{~m}, 1 \mathrm{H}, \mathrm{H}^{\prime}\right), 4.25$ (apparent $\mathrm{t}, J=2.4 \mathrm{~Hz}, 2 \mathrm{H}, \underline{\mathrm{CH}}_{2} \mathrm{C} \equiv$ $\mathrm{CH}), 4.13-4.12\left(\mathrm{~m}, 1 \mathrm{H}, \mathrm{H}^{\prime}\right), 3.74\left(\mathrm{~s}, 6 \mathrm{H}, 2 \times \mathrm{OCH}_{3}\right), 3.53$ $(\mathrm{t}, J=2.4 \mathrm{~Hz}, 1 \mathrm{H}, \mathrm{C} \equiv \mathrm{CH}), 3.32-3.29\left(\mathrm{~m}, 1 \mathrm{H}, \mathrm{H} 5^{\prime}\right), 3.23(\mathrm{dd}$, $\left.J=10.4,2.8 \mathrm{~Hz}, 1 \mathrm{H}, \mathrm{H} 5^{\prime}\right), 2.46-2.39\left(\mathrm{~m}, 2 \mathrm{H}, \mathrm{H} 2^{\prime}\right), 1.81(\mathrm{~s}$, $\left.3 \mathrm{H}, \mathrm{CH}_{3}\right) \cdot{ }^{13} \mathrm{C}$ NMR (100 MHz, DMSO) $\delta 159.2(\mathrm{C} 4), 158.7$ (DMTr), 145.0 (C2), 138.5 (C6), 137.0, 135.8, 135.6, 133.0, 130.2, 129.8, 128.8, 128.5, 128.1, 127.3, 113.8 (DMTr, Ph), 110.7 (C5), 86.7 (DMTr), $85.6\left(\mathrm{C1}^{\prime}\right), 83.6\left(\mathrm{C}^{\prime}\right), 80.4$ (C” $\underline{\mathrm{CH}}), 78.2(\underline{\mathrm{C}} \equiv \mathrm{CH}), 78.0\left(\mathrm{H}^{\prime}\right), 63.9\left(\mathrm{C5}^{\prime}\right), 56.5\left(\mathrm{CH}_{2}\right), 55.5$ $\left(2 \times \mathrm{OCH}_{3}\right), 37.2\left(\mathrm{C}^{\prime}\right), 13.2\left(\mathrm{CH}_{3}\right)$.

5'-Azido-5'-deoxythymidine-LNA (6). To a solution of nucleoside $5^{29}(1.0 \mathrm{~g}, 2.28 \mathrm{mmol})$ in $\mathrm{MeOH}(15 \mathrm{~mL})$ was added $\mathrm{Pd}(\mathrm{OH})_{2} / \mathrm{C}(20 \mathrm{wt} \%$ loading, $200 \mathrm{mg})$. The mixture was degassed with argon $(5 \mathrm{~min})$ and then with hydrogen (10 $\mathrm{min}$ ). The reaction mixture was stirred under hydrogen at room temperature for $16 \mathrm{~h}$. The catalyst was filtered off and the filter cake was washed with $\mathrm{MeOH}(50 \mathrm{~mL})$. The filtrate was concentrated under reduced pressure and the residue was dissolved in DMF $(10 \mathrm{~mL}) . \mathrm{NaN}_{3}(300 \mathrm{mg}, 4.61 \mathrm{mmol})$ was added and the reaction mixture was stirred at $90{ }^{\circ} \mathrm{C}$ for $2 \mathrm{~h}$. The solvent was removed under reduced pressure and the residue was purified using column chromatography (0-7\% $\mathrm{MeOH}$ in $\left.\mathrm{CH}_{2} \mathrm{Cl}_{2}\right)$ to afford nucleoside $6(0.43 \mathrm{~g}, 64 \%)$ as white foam. $R_{f}\left(0.5,7 \% \mathrm{MeOH}\right.$ in $\left.\mathrm{CH}_{2} \mathrm{Cl}_{2}\right)$. ESI HRMS $\mathrm{m} / z$ $318.0810([\mathrm{M}+\mathrm{Na}])^{+}, \mathrm{C}_{11} \mathrm{H}_{13} \mathrm{O}_{5} \mathrm{~N}_{5} \mathrm{Na}^{+}$calc. 318.0809. ${ }^{1} \mathrm{H}$ NMR (500 MHz, DMSO) $\delta 11.40(\mathrm{~s}, 1 \mathrm{H}, \mathrm{NH}), 7.48(\mathrm{~d}, J=1.2$ $\mathrm{Hz}, 1 \mathrm{H}, \mathrm{H6}$ ), 5.88 (bs, 1H, 3'-OH), 5.48 (s, 1H, H1'), 4.20 (s, $1 \mathrm{H}, \mathrm{H} 2^{\prime}$ ), 3.99 (d, $\left.J=14.0 \mathrm{~Hz}, 1 \mathrm{H}, \mathrm{H} 5^{\prime \prime}\right), 3.92$ (s, 1H, H3'), 3.88 (d, $\left.J=8.0 \mathrm{~Hz}, 1 \mathrm{H}, \mathrm{H} 5^{\prime \prime}\right), 3.79$ (d, $J=14.0 \mathrm{~Hz}, 1 \mathrm{H}, \mathrm{H} 5^{\prime}$ ), $3.74\left(\mathrm{~d}, J=8.0 \mathrm{~Hz}, 1 \mathrm{H}, \mathrm{H}^{\prime}\right), 1.82\left(\mathrm{~d}, J=1.2 \mathrm{~Hz}, 3 \mathrm{H}, \mathrm{CH}_{3}\right)$. ${ }^{13} \mathrm{C}$ NMR (126 MHz, DMSO) $\delta 164.2$ (C4), 150.4 (C2), 134.8 (C6), 109.2 (C5), 87.4 (C4'), $87.1\left(\mathrm{Cl}^{\prime}\right), 79.5$ (C2'), 71.6 (C5"), 70.4 (C3'), 47.9 ( $\left.\mathrm{C5}^{\prime}\right), 12.8\left(\mathrm{CH}_{3}\right)$.

Synthesis of DNA/DNA Triazole Nucleoside (8). Nucleosides 4 (0.50 g, $0.73 \mathrm{mmol})$ and $7(175 \mathrm{mg}, 0.66$ $\mathrm{mmol})$ were dissolved in $\mathrm{THF} / \mathrm{H}_{2} \mathrm{O} / \mathrm{t}-\mathrm{BuOH}(10 \mathrm{~mL}, 3: 1: 1, \mathrm{v} /$ $\mathrm{v} / \mathrm{v})$. To this solution was added pyridine (2-3 drops), $\mathrm{CuSO}_{4}$ (1.5 mL, 7.5\% aqueous, $\mathrm{w} / \mathrm{v})$, and sodium ascorbate $(1.7 \mathrm{~mL}, 1$ $\mathrm{M}$ aqueous). The reaction mixture was degassed with argon and stirred at room temperature for $2 \mathrm{~h}$. The reaction was diluted with EtOAc $(100 \mathrm{~mL})$ and washed with $\mathrm{H}_{2} \mathrm{O}(50 \mathrm{~mL})$ followed by sat. aqueous solution of ethylenediaminetetraacetic acid (EDTA) $(3 \times 50 \mathrm{~mL})$. The combined aqueous phase was back extracted with EtOAc $(50 \mathrm{~mL})$ and the combined organic phases were dried $\left(\mathrm{Na}_{2} \mathrm{SO}_{4}\right)$ and concentrated under reduced pressure. The residue was purified using column chromatography $\left(0-6 \% \mathrm{MeOH}\right.$ in $\left.\mathrm{CH}_{2} \mathrm{Cl}_{2}\right)$ to obtain $8(0.50 \mathrm{~g}, 80 \%)$ as a white foam. $R_{f}\left(0.4,6 \% \mathrm{MeOH}\right.$ in $\left.\mathrm{CH}_{2} \mathrm{Cl}_{2}\right)$. ESI HRMS $\mathrm{m} / z$ 953.3824 $([\mathrm{M}+\mathrm{H}])^{+}, \mathrm{C}_{51} \mathrm{H}_{53} \mathrm{O}_{11} \mathrm{~N}_{8}{ }^{+}$calc. 953.3828. ${ }^{1} \mathrm{H}$ NMR $(500 \mathrm{MHz}, \mathrm{DMSO}) \delta 12.96\left(\mathrm{~s}, 1 \mathrm{H}, \mathrm{NH}\left({ }^{\mathrm{Me}} \mathrm{C}\right)\right), 11.32(\mathrm{~s}, 1 \mathrm{H}$, $\mathrm{NH}(\mathrm{T})), 8.19(\mathrm{~m}, 2 \mathrm{H}, \mathrm{Ph}), 8.10(\mathrm{~s}, 1 \mathrm{H}$, triazole-H), $7.82(\mathrm{~s}$, 1H, H6 $\left.\left({ }^{\mathrm{Me}} \mathrm{C}\right)\right), 7.60(\mathrm{~m}, 1 \mathrm{H}, \mathrm{Ph}), 7.50(\mathrm{~m}, 2 \mathrm{H}, \mathrm{Ph}), 7.40-7.39$ (m, 2H, DMTr), 7.35-7.32 (m, 3H, DMTr, H6 (T)), 7.287.24 (m, 5H, DMTr), 6.93-6.91 (m, 4H, DMTr), 6.18-6.15 $\left.\left(\mathrm{m}, 2 \mathrm{H}, \mathrm{Hl}^{\prime}(\mathrm{T}), \mathrm{H1}^{\prime}{ }^{\mathrm{Me}} \mathrm{C}\right)\right), 5.52\left(\mathrm{~d}, J=4.4 \mathrm{~Hz}, 1 \mathrm{H}, 3^{\prime}-\mathrm{OH}\right.$ (T)), 4.71 (dd, $\left.J=14.2,4.4 \mathrm{~Hz}, 1 \mathrm{H}, \mathrm{H}^{\prime}(\mathrm{T})\right), 4.63-4.56$ (m, $\left.3 \mathrm{H}, \mathrm{H}^{\prime}(\mathrm{T}), \mathrm{CH}_{2}\right), 4.46-4.44\left(\mathrm{~m}, 1 \mathrm{H}, \mathrm{H}^{\prime}\left({ }^{\mathrm{Me}} \mathrm{C}\right)\right), 4.31-4.27$ $\left(\mathrm{m}, 1 \mathrm{H}, \mathrm{H} 3^{\prime}(\mathrm{T})\right), 4.13-4.12\left(\mathrm{~m}, 1 \mathrm{H}, \mathrm{H} 4^{\prime}\left({ }^{\mathrm{Me}} \mathrm{C}\right)\right), 4.10-4.06$ $\left(\mathrm{m}, 1 \mathrm{H}, \mathrm{H}^{\prime}(\mathrm{T})\right), 3.76\left(\mathrm{~s}, 6 \mathrm{H}, 2 \times \mathrm{OCH}_{3}\right), 3.31(\mathrm{dd}, J=9.8$, $\left.4.4 \mathrm{~Hz}, 1 \mathrm{H}, \mathrm{H}^{\prime}\left({ }^{\mathrm{Me}} \mathrm{C}\right)\right), 3.23-3.22\left(\mathrm{~m}, 1 \mathrm{H}, \mathrm{H}^{\prime}\left({ }^{\mathrm{Me}} \mathrm{C}\right)\right), 2.46-$ $2.42\left(\mathrm{~m}, 2 \mathrm{H}, \mathrm{H} 2^{\prime}\left({ }^{\mathrm{Me}} \mathrm{C}\right)\right), 2.22-2.17\left(\mathrm{~m}, 1 \mathrm{H}, \mathrm{H} 2^{\prime}(\mathrm{T})\right), 2.13-$ $2.09\left(\mathrm{~m}, 1 \mathrm{H}, \mathrm{H} 2^{\prime}(\mathrm{T})\right), 1.79\left(\mathrm{dd}, J=0.9 \mathrm{~Hz}, 3 \mathrm{H}, \mathrm{CH}_{3}(\mathrm{~T})\right)$, $1.68\left(\mathrm{~s}, 3 \mathrm{H}, \mathrm{CH}_{3}\left({ }^{\mathrm{Me}} \mathrm{C}\right)\right) .{ }^{13} \mathrm{C}$ NMR (126 MHz, DMSO) $\delta$ $178.6,164.1,159.2,158.7,150.8,145.1,144.2$, 138.6, 137.1, $136.5,135.8,135.6,133.0,130.2,129.9,128.8,128.5,128.1$, $127.3,125.2$, 113.8, 110.7, 110.3, 86.6, 85.4, 84.5, 84.4, 83.8, 78.9, 71.2, 64.0, 62.3, 55.5, 51.6, 38.4, 37.4, 13.0, 12.5 .

Synthesis of DNA/LNA Triazole Nucleoside (9). Nucleosides 4 (237 mg, $0.80 \mathrm{mmol})$ and 6 (0.60 g, 0.88 $\mathrm{mmol})$ were dissolved in $\mathrm{THF} / \mathrm{H}_{2} \mathrm{O} / \mathrm{t}-\mathrm{BuOH}(10 \mathrm{~mL}, 3: 1: 1, \mathrm{v} /$ $\mathrm{v} / \mathrm{v}$ ). To this solution was added pyridine (2-3 drops), $\mathrm{CuSO}_{4}$ $(1.8 \mathrm{~mL}, 7.5 \%$ aqueous, $\mathrm{w} / \mathrm{v})$, and sodium ascorbate $(2.0 \mathrm{~mL}, 1$ $\mathrm{M}$ aqueous). The reaction mixture was degassed with argon and stirred at room temperature for $2 \mathrm{~h}$. The reaction was diluted with EtOAc $(100 \mathrm{~mL})$ and washed with $\mathrm{H}_{2} \mathrm{O}(50 \mathrm{~mL})$ and sat. aqueous solution of EDTA $(3 \times 50 \mathrm{~mL})$. The combined aqueous phase was back extracted with EtOAc $(50 \mathrm{~mL})$ and the combined organic phase was dried $\left(\mathrm{Na}_{2} \mathrm{SO}_{4}\right)$ and concentrated under reduced pressure. The residue was purified using column chromatography $\left(0-6 \% \mathrm{MeOH}\right.$ in $\left.\mathrm{CH}_{2} \mathrm{Cl}_{2}\right)$ to obtain $9(0.65$ g, $82 \%)$ as a white foam. $R_{f}\left(0.4,6 \% \mathrm{MeOH}\right.$ in $\left.\mathrm{CH}_{2} \mathrm{Cl}_{2}\right)$. ESI HRMS $m / z$ 979.3617 $([\mathrm{M}-\mathrm{H}])^{-}, \mathrm{C}_{52} \mathrm{H}_{51} \mathrm{O}_{12} \mathrm{~N}_{8}{ }^{-}$calc. 979.3631. ${ }^{1} \mathrm{H}$ NMR (500 MHz, DMSO) $\delta 12.96(\mathrm{~s}, 1 \mathrm{H}, \mathrm{NH}$ $\left.\left({ }^{\mathrm{Me}} \mathrm{C}\right)\right), 11.35(\mathrm{~s}, 1 \mathrm{H}, \mathrm{NH}(\mathrm{T})), 8.21-8.17(\mathrm{~m}, 3 \mathrm{H}, \mathrm{Ph}$, triazole-H), $7.82\left(\mathrm{~s}, 1 \mathrm{H}, \mathrm{H} 6\left({ }^{\mathrm{Me}} \mathrm{C}\right)\right), 7.60(\mathrm{~m}, 1 \mathrm{H}, \mathrm{Ph}), 7.50(\mathrm{~m}$, $2 \mathrm{H}, \mathrm{Ph}), 7.41-7.39(\mathrm{~m}, 2 \mathrm{H}, \mathrm{DMTr}), 7.34(\mathrm{t}, J=7.8 \mathrm{~Hz}, 2 \mathrm{H}$, 
DMTr), 7.28-7.23 (m, 5H, DMTr), 6.92 (d, $J=8.8 \mathrm{~Hz}, 4 \mathrm{H}$, DMTr), 6.60 (d, $J=1.3 \mathrm{~Hz}, 1 \mathrm{H}, \mathrm{H} 6(\mathrm{~T})), 6.16(\mathrm{t}, J=6.7 \mathrm{~Hz}$, $\left.1 \mathrm{H}, \mathrm{H1} 1^{\prime}\left({ }^{\mathrm{Me}} \mathrm{C}\right)\right), 6.08\left(\mathrm{~d}, J=6.1 \mathrm{~Hz}, 1 \mathrm{H}, 3^{\prime}-\mathrm{OH}\right), 5.40(\mathrm{~s}, 1 \mathrm{H}$, $\mathrm{H1}^{\prime}(\mathrm{T})$ ), 4.99 (d, J = $\left.15.1 \mathrm{~Hz}, 1 \mathrm{H}, \mathrm{H} 5^{\prime}(\mathrm{T})\right), 4.88$ (d, $J=15.1$ $\left.\mathrm{Hz}, 1 \mathrm{H}, \mathrm{H5}^{\prime}(\mathrm{T})\right), 4.66\left(\mathrm{~d}, J=12.0 \mathrm{~Hz}, 1 \mathrm{H}, \mathrm{CH}_{2}\right), 4.62(\mathrm{~d}, J=$ $\left.12.0 \mathrm{~Hz}, 1 \mathrm{H}, \mathrm{CH}_{2}\right), 4.48-4.45\left(\mathrm{~m}, 1 \mathrm{H}, \mathrm{H}^{\prime}{ }^{\prime}\left({ }^{\mathrm{Me}} \mathrm{C}\right)\right), 4.18(\mathrm{~s}$, $\left.1 \mathrm{H}, \mathrm{H} 2^{\prime}(\mathrm{T})\right), 4.14-4.12\left(\mathrm{~m}, 1 \mathrm{H}, \mathrm{H} 4^{\prime}\left({ }^{\mathrm{Me}} \mathrm{C}\right)\right), 4.03(\mathrm{~d}, J=8.0$ Hz, 1H, H5" (T)), 3.79 (d, J = 3.3 Hz, H3' (T)), 3.74 (s, 6H, 2 $\left.\times \mathrm{OCH}_{3}\right), 3.59\left(\mathrm{~d}, J=8.0 \mathrm{~Hz}, 1 \mathrm{H}, \mathrm{H}^{\prime \prime}(\mathrm{T})\right), 3.32-3.20(\mathrm{~m}$, $\left.1 \mathrm{H}, \mathrm{H}^{\prime}\left({ }^{\mathrm{Me}} \mathrm{C}\right)\right), 3.25-3.23\left(\mathrm{~m}, 1 \mathrm{H}, \mathrm{H}^{\prime}\left({ }^{\mathrm{Me}} \mathrm{C}\right)\right), 2.47-2.41$ (m, 2H, H2' $\left.\left({ }^{\mathrm{Me}} \mathrm{C}\right)\right), 1.67$ (app s, $6 \mathrm{H}, 2 \times \mathrm{CH}_{3}\left({ }^{\mathrm{Me}} \mathrm{C}\right.$ and $\left.\mathrm{T}\right)$ ). ${ }^{13} \mathrm{C}$ NMR (126 MHz, DMSO) $\delta 164.1,158.7,158.6,150.2$, $145.1,144.3,135.8,135.6,134.1,133.0,130.2,129.8,128.8$, $128.5,128.1,127.3,126.3,113.8,109.1,87.1,86.6,86.3,83.9$, 79.5, 79.0, 71.8, 70.4, 64.0, 62.4, 55.5, 46.5, 13.1, 12.5 .

Synthesis of LNA/DNA Triazole Nucleoside (10). Nucleosides 3 (0.50 g, $0.73 \mathrm{mmol})$ and 7 (170 mg, 0.66 $\mathrm{mmol})$ were dissolved in $\mathrm{THF} / \mathrm{H}_{2} \mathrm{O} / \mathrm{t}-\mathrm{BuOH}(10 \mathrm{~mL}, 3: 1: 1, \mathrm{v} /$ $\mathrm{v} / \mathrm{v})$. To this solution was added pyridine (2-3 drops), $\mathrm{CuSO}_{4}$ $(1.5 \mathrm{~mL}, 7.5 \%$ aqueous, $\mathrm{w} / \mathrm{v})$, and sodium ascorbate $(1.7 \mathrm{~mL}, 1$ $\mathrm{M}$ aqueous). The reaction mixture was degassed with argon and stirred at room temperature for $2 \mathrm{~h}$. The reaction was diluted with EtOAc $(100 \mathrm{~mL})$ and washed with $\mathrm{H}_{2} \mathrm{O}(50 \mathrm{~mL})$ and sat. aqueous solution of EDTA $(3 \times 50 \mathrm{~mL})$. The combined aqueous phase was back extracted with EtOAc $(50 \mathrm{~mL})$ and the combined organic phase was dried $\left(\mathrm{Na}_{2} \mathrm{SO}_{4}\right)$ and concentrated under reduced pressure. The residue was purified using column chromatography $\left(0-6 \% \mathrm{MeOH}\right.$ in $\left.\mathrm{CH}_{2} \mathrm{Cl}_{2}\right)$ to obtain 10 (0.54 g, $87 \%)$ as a white foam. $R_{f}\left(0.5,7 \% \mathrm{MeOH}\right.$ in $\left.\mathrm{CH}_{2} \mathrm{Cl}_{2}\right)$. ESI HRMS $m / z$ 979.3621 $([\mathrm{M}-\mathrm{H}])^{-}, \mathrm{C}_{52} \mathrm{H}_{51} \mathrm{O}_{12} \mathrm{~N}_{8}{ }^{-}$calc. 979.3631. ${ }^{1} \mathrm{H}$ NMR (500 MHz, DMSO) $\delta 13.16(\mathrm{~s}, 1 \mathrm{H}, \mathrm{NH}$ $\left.\left({ }^{\mathrm{Me}} \mathrm{C}\right)\right), 11.31(\mathrm{~s}, 1 \mathrm{H}, \mathrm{NH}(\mathrm{T})), 8.23(\mathrm{~m}, 2 \mathrm{H}, \mathrm{Ph}), 8.03(\mathrm{~s}, 1 \mathrm{H}$, triazole-H), $7.85\left(\mathrm{~s}, 1 \mathrm{H}, \mathrm{H} 6\left({ }^{\mathrm{Me}} \mathrm{C}\right)\right), 7.61(\mathrm{~m}, 1 \mathrm{H}, \mathrm{Ph}), 7.52(\mathrm{~m}$, $2 \mathrm{H}, \mathrm{Ph}), 7.42-7.42(\mathrm{~m}, 2 \mathrm{H}, \mathrm{DMTr}), 7.34-7.23(\mathrm{~m}, 8 \mathrm{H}$, DMTr, H6 (T)), 6.93-6.90 (m, 4H, DMTr), $6.16(\mathrm{t}, J=7.0$ $\left.\mathrm{Hz}, 1 \mathrm{H}, \mathrm{H1}^{\prime}(\mathrm{T})\right), 5.60\left(\mathrm{~s}, 1 \mathrm{H}, \mathrm{H}^{\prime}{ }^{\left({ }^{\mathrm{Me}} \mathrm{C}\right)}\right), 5.50(\mathrm{~d}, J=4.3 \mathrm{~Hz}$, $\left.1 \mathrm{H}, 3^{\prime}-\mathrm{OH}(\mathrm{T})\right), 4.72\left(\mathrm{~d}, J=12.0 \mathrm{~Hz}, 1 \mathrm{H}, \mathrm{CH}_{2}\right), 4.68-4.64$ $\left(\mathrm{m}, 3 \mathrm{H}, \mathrm{H} 2^{\prime}\left({ }^{\mathrm{Me}} \mathrm{C}\right), \mathrm{CH}_{2}, \mathrm{H}^{\prime}(\mathrm{T})\right), 4.58(\mathrm{dd}, J=14.3,7.6 \mathrm{~Hz}$, $\left.1 \mathrm{H}, \mathrm{H}^{\prime}(\mathrm{T})\right), 4.41$ (s, 1H, H3' $\left.{ }^{{ }^{\mathrm{Me}} \mathrm{C}} \mathrm{C}\right)$, 4.29-4.25 (m, 1H, H3' (T)), 4.07-4.04 (m, 1H, H4' (T)), 3.75-3.71 (m, 8H, $2 \times$ $\left.\mathrm{OCH}_{3}, 2 \times \mathrm{H}^{\prime \prime}\left({ }^{\mathrm{Me}} \mathrm{C}\right)\right), 3.41\left(\mathrm{~d}, J=11.2 \mathrm{~Hz}, 1 \mathrm{H}, \mathrm{H}^{\prime}\left({ }^{\mathrm{Me}} \mathrm{C}\right)\right)$, 3.36-3.31 (m, 1H, $\mathrm{H}^{\prime}\left({ }^{\mathrm{Me}} \mathrm{C}\right)$, merged with $\mathrm{H}_{2} \mathrm{O}$ signal from DMSO), 2.21-2.15 (m, 1H, H2' (T)), 2.12-2.07 (m, 1H, H2' (T)), 1.86 (s, 3H, $\left.\mathrm{CH}_{3},\left({ }^{\mathrm{Me}} \mathrm{C}\right)\right), 1.76\left(\mathrm{~d}, \mathrm{~J}=1.2 \mathrm{~Hz}, 3 \mathrm{H}, \mathrm{CH}_{3}\right.$ (T)). ${ }^{13} \mathrm{C}$ NMR (126 MHz, DMSO) $\delta 178.7,164.1,159.7$, $158.6,150.8,145.0,143.9,137.4,137.1,136.5,135.7,135.4$, $133.0,130.2,129.8,128.8,128.5,128.0,127.3,125.2,113.8$, $110.3,109.9,87.6,87.4,86.3,84.5,84.4,76.6,76.5,72.2,71.2$, 63.1, 58.4, 55.5, 51.7, 38.4, 14.0, 12.5 .

Synthesis of LNA/LNA Triazole Nucleoside (11). Nucleosides $3(120 \mathrm{mg}, 0.40 \mathrm{mmol})$ and 6 (0.36 g, 0.50 $\mathrm{mmol}$ ) were dissolved in $\mathrm{THF} / \mathrm{H}_{2} \mathrm{O} / \mathrm{t}-\mathrm{BuOH}(5 \mathrm{~mL}, 3: 1: 1, \mathrm{v} /$ $\mathrm{v} / \mathrm{v})$. To this solution was added pyridine (2-3 drops), $\mathrm{CuSO}_{4}$ $(0.9 \mathrm{~mL}, 7.5 \%$ aqueous, $\mathrm{w} / \mathrm{v})$, and sodium ascorbate $(1.0 \mathrm{~mL}, 1$ $\mathrm{M}$ aqueous). The reaction mixture was degassed with argon and stirred at room temperature for $2 \mathrm{~h}$. The reaction was diluted with EtOAc $(50 \mathrm{~mL})$ and washed with $\mathrm{H}_{2} \mathrm{O}(30 \mathrm{~mL})$ and a sat. aqueous solution of EDTA $(3 \times 30 \mathrm{~mL})$. The combined aqueous phase was back extracted with EtOAc $(20 \mathrm{~mL})$ and the combined organic phase was dried $\left(\mathrm{Na}_{2} \mathrm{SO}_{4}\right)$ and concentrated under reduced pressure. The residue was purified using column chromatography $\left(0-6 \% \mathrm{MeOH}\right.$ in $\left.\mathrm{CH}_{2} \mathrm{Cl}_{2}\right)$ to obtain 11 (0.32 $\mathrm{g}, 79 \%)$ as a white foam with a small amount of EtOAc as an impurity. $R_{f}\left(0.4,6 \% \mathrm{MeOH}\right.$ in $\left.\mathrm{CH}_{2} \mathrm{Cl}_{2}\right)$. ESI HRMS $\mathrm{m} / z$ 1009.3721 $([\mathrm{M}+\mathrm{H}])^{+}, \mathrm{C}_{53} \mathrm{H}_{53} \mathrm{O}_{13} \mathrm{~N}_{8}{ }^{+}$calc. 1009.3726. ${ }^{1} \mathrm{H}$ NMR (500 MHz, DMSO) $\delta 13.16$ (bs, $\left.1 \mathrm{H}, \mathrm{NH}\left({ }^{\mathrm{Me}} \mathrm{C}\right)\right), 11.33$ (s, 1H, NH (T)), $8.19(\mathrm{~m}, 2 \mathrm{H}, \mathrm{Ph}), 8.12(\mathrm{~s}, 1 \mathrm{H}$, triazole-H), $7.86\left(\mathrm{~s}, 1 \mathrm{H}, \mathrm{H} 6\left({ }^{\mathrm{Me}} \mathrm{C}\right)\right), 7.60(\mathrm{~m}, 1 \mathrm{H}, \mathrm{Ph}), 7.50(\mathrm{~m}, 2 \mathrm{H}, \mathrm{Ph})$, 7.43-7.41 (m, 2H, DMTr), 7.34-7.22 (m, 7H, DMTr), 6.926.88 (m, 4H, DMTr), 6.62 (s, 1H, H6 (T)), 6.05 (d, J = 4.2 Hz, $\left.1 \mathrm{H}, 3^{\prime}-\mathrm{OH}(\mathrm{T})\right), 5.60\left(\mathrm{~s}, 1 \mathrm{H}, \mathrm{H}^{\prime}\left({ }^{\mathrm{Me}} \mathrm{C}\right)\right), 5.40\left(\mathrm{~s}, 1 \mathrm{H}, \mathrm{H}^{\prime}\right.$ (T)), 4.97 (d, $\left.J=15.2 \mathrm{~Hz}, 1 \mathrm{H}, \mathrm{HS}^{\prime}(\mathrm{T})\right), 4.82(\mathrm{~d}, J=15.2 \mathrm{~Hz}$, $\left.1 \mathrm{H}, \mathrm{H}^{\prime}(\mathrm{T})\right), 4.77\left(\mathrm{~d}, J=12.1 \mathrm{~Hz}, 1 \mathrm{H}, \mathrm{CH}_{2}\right), 4.70-4.66(\mathrm{~m}$, $\left.2 \mathrm{H}, \mathrm{CH}_{2}, \mathrm{H}^{\prime}\left({ }^{\mathrm{Me}} \mathrm{C}\right)\right), 4.43\left(\mathrm{~s}, 1 \mathrm{H}, \mathrm{H} 2^{\prime}\left({ }^{\mathrm{Me}} \mathrm{C}\right)\right), 4.16(\mathrm{~s}, 1 \mathrm{H}$, $\left.\mathrm{H}^{\prime}(\mathrm{T})\right), 3.98$ (d, $\left.J=8.0 \mathrm{~Hz}, 1 \mathrm{H}, \mathrm{H}^{\prime \prime}(\mathrm{T})\right), 3.80$ (d, $J=4.2$ $\left.\mathrm{Hz}, 1 \mathrm{H}, \mathrm{H}^{\prime}(\mathrm{T})\right), 3.75-3.72\left(\mathrm{~m}, 8 \mathrm{H}, 2 \times \mathrm{OCH}_{3}, 2 \times \mathrm{H}^{\prime \prime}\right.$ $\left.\left({ }^{\mathrm{Me}} \mathrm{C}\right)\right), 3.50\left(\mathrm{~d}, J=8.0 \mathrm{~Hz}, 1 \mathrm{H}, \mathrm{H} 5^{\prime \prime}(\mathrm{T})\right), 3.41-3.36(\mathrm{~m}, 2 \mathrm{H}$, $\left.2 \times \mathrm{H}^{\prime}\left({ }^{\mathrm{Me}} \mathrm{C}\right)\right), 1.85\left(\mathrm{~s}, 3 \mathrm{H}, \mathrm{CH}_{3},\left({ }^{\mathrm{Me}} \mathrm{C}\right)\right), 1.61\left(\mathrm{~s}, 3 \mathrm{H}, \mathrm{CH}_{3}\right.$ (T)). ${ }^{13} \mathrm{C}$ NMR (126 MHz, DMSO) $\delta 164.1,158.7,150.2$, $145.1,144.0,137.2,135.6,135.5,134.2,133.0,130.2,129.8$, $128.8,128.5,128.0,127.3,126.2,113.8,109.1,87.6,87.5,87.1$, $86.3,79.5,76.6,76.5,72.2,71.7,70.4,63.1,58.5,55.5,46.6$, $14.0,12.5$. Some quarternary carbons are not seen in the NMR

Synthesis of DNA/DNA Triazole Phosphoramidite (12). Nucleoside $8(250 \mathrm{mg}, 0.26 \mathrm{mmol})$ was dissolved in dry $\mathrm{CH}_{2} \mathrm{Cl}_{2}(5 \mathrm{~mL})$. DIPEA $(200 \mu \mathrm{L}, 1.14 \mathrm{mmol})$ and 2cyanoethyl $\mathrm{N}, \mathrm{N}$-diisopropylchlorophosphoramidite $(120 \mu \mathrm{L}$, $0.56 \mathrm{mmol}$ ) were added and the reaction mixture was stirred at room temperature for $2 \mathrm{~h}$. The reaction was diluted with $\mathrm{CH}_{2} \mathrm{Cl}_{2}(30 \mathrm{~mL})$ and washed with sat. aqueous $\mathrm{KCl}(30 \mathrm{~mL})$. The organic phase was dried $\left(\mathrm{Na}_{2} \mathrm{SO}_{4}\right)$ and concentrated under reduced pressure. The residue was purified using column chromatography $\left(0-3 \% \mathrm{MeOH}\right.$ in $\left.\mathrm{CH}_{2} \mathrm{Cl}_{2}\right)$ to obtain 12 (150 mg, $50 \%)$ as a white foam. $R_{f}\left(0.4,3 \% \mathrm{MeOH}\right.$ in $\left.\mathrm{CH}_{2} \mathrm{Cl}_{2}\right)$. ESI HRMS $m / z 1153.4915([\mathrm{M}+\mathrm{H}])^{+}, \mathrm{C}_{60} \mathrm{H}_{70} \mathrm{O}_{12} \mathrm{~N}_{10} \mathrm{P}^{+}$calc. 1153.4906. ${ }^{31} \mathrm{P}$ NMR (162 MHz, $\left.\mathrm{CD}_{3} \mathrm{CN}\right) \delta 148.76,148.53$.

Synthesis of DNA/LNA Triazole Phosphoramidite (13). Nucleoside $9(300 \mathrm{mg}, 0.31 \mathrm{mmol})$ was dissolved in dry $\mathrm{CH}_{2} \mathrm{Cl}_{2}(5 \mathrm{~mL})$. DIPEA $(0.22 \mathrm{~mL}, 1.24 \mathrm{mmol})$ and 2cyanoethyl $\mathrm{N}, \mathrm{N}$-diisopropylchlorophosphoramidite $(0.14 \mathrm{~mL}$, $0.62 \mathrm{mmol}$ ) were added and the reaction mixture was stirred at room temperature for $2 \mathrm{~h}$. The reaction was diluted with $\mathrm{CH}_{2} \mathrm{Cl}_{2}(30 \mathrm{~mL})$ and washed with sat. aqueous $\mathrm{KCl}(30 \mathrm{~mL})$. The organic phase was dried $\left(\mathrm{Na}_{2} \mathrm{SO}_{4}\right)$ and concentrated under reduced pressure. The residue was purified using column chromatography $\left(0-3 \% \mathrm{MeOH}\right.$ in $\left.\mathrm{CH}_{2} \mathrm{Cl}_{2}\right)$ to obtain 13 (225 $\mathrm{mg}, 62 \%)$ as a white foam. $R_{f}\left(0.5,4 \% \mathrm{MeOH}\right.$ in $\left.\mathrm{CH}_{2} \mathrm{Cl}_{2}\right)$. ESI HRMS $m / z$ 1181.4861 $([\mathrm{M}+\mathrm{H}])^{+}, \mathrm{C}_{61} \mathrm{H}_{70} \mathrm{O}_{13} \mathrm{~N}_{10} \mathrm{P}^{+}$calc. 1181.4856. ${ }^{31} \mathrm{P}$ NMR (162 MHz, $\left.\mathrm{CD}_{3} \mathrm{CN}\right) \delta 149.22,148.86$.

Synthesis of LNA/DNA Triazole Phosphoramidite (14). Nucleoside 10 (350 mg, $0.36 \mathrm{mmol}$ ) was dissolved in dry $\mathrm{CH}_{2} \mathrm{Cl}_{2}(5 \mathrm{~mL})$. DIPEA $(250 \mu \mathrm{L}, 1.44 \mathrm{mmol})$ and 2-cyanoethyl $N, N$-diisopropylchlorophosphoramidite $(180 \mu \mathrm{L}, 0.72 \mathrm{mmol})$ were added and the reaction mixture was stirred at room temperature for $2 \mathrm{~h}$. The reaction was diluted with $\mathrm{CH}_{2} \mathrm{Cl}_{2}(30$ $\mathrm{mL})$ and washed with sat. aqueous $\mathrm{KCl}(30 \mathrm{~mL})$. The organic phase was dried $\left(\mathrm{Na}_{2} \mathrm{SO}_{4}\right)$ and concentrated under reduced pressure. The residue was purified using column chromatography $\left(0-3 \% \mathrm{MeOH}\right.$ in $\left.\mathrm{CH}_{2} \mathrm{Cl}_{2}\right)$ to obtain $14(320 \mathrm{mg}, 76 \%)$ as a white foam. $R_{f}\left(0.5,5 \% \mathrm{MeOH}\right.$ in $\left.\mathrm{CH}_{2} \mathrm{Cl}_{2}\right)$. ESI HRMS $m /$ $z 1181.4859([\mathrm{M}+\mathrm{H}])^{+}, \mathrm{C}_{61} \mathrm{H}_{70} \mathrm{O}_{13} \mathrm{~N}_{10} \mathrm{P}^{+}$calc. $1181.4856 .{ }^{31} \mathrm{P}$ NMR (162 MHz, $\left.\mathrm{CD}_{3} \mathrm{CN}\right) \delta 148.69,148.55$.

Synthesis of LNA/LNA Triazole Phosphoramidite (15). Nucleoside 11 (280 mg, $0.28 \mathrm{mmol})$ was dissolved in dry $\mathrm{CH}_{2} \mathrm{Cl}_{2}(5 \mathrm{~mL})$. DIPEA $(0.18 \mathrm{~mL}, 1.03 \mathrm{mmol})$ and 2cyanoethyl $\mathrm{N}, \mathrm{N}$-diisopropylchlorophosphoramidite $(136 \mu \mathrm{L}$, 
$0.58 \mathrm{mmol}$ ) were added and the reaction mixture was stirred at room temperature for $2 \mathrm{~h}$. The reaction was diluted with $\mathrm{CH}_{2} \mathrm{Cl}_{2}(30 \mathrm{~mL})$ and washed with sat. aqueous $\mathrm{KCl}(30 \mathrm{~mL})$. The organic phase was dried $\left(\mathrm{Na}_{2} \mathrm{SO}_{4}\right)$ and concentrated under reduced pressure. The residue was purified using column chromatography $\left(0-3 \% \mathrm{MeOH}\right.$ in $\left.\mathrm{CH}_{2} \mathrm{Cl}_{2}\right)$ to obtain 15 (245 mg, $73 \%)$ as a white foam. $R_{f}\left(0.5,4 \% \mathrm{MeOH}\right.$ in $\left.\mathrm{CH}_{2} \mathrm{Cl}_{2}\right)$. ESI HRMS $m / z 1209.4813([\mathrm{M}+\mathrm{H}])^{+}, \mathrm{C}_{62} \mathrm{H}_{70} \mathrm{O}_{14} \mathrm{~N}_{10} \mathrm{P}^{+}$calc. 1209.4805. ${ }^{31} \mathrm{P}$ NMR (162 MHz, $\left.\mathrm{CD}_{3} \mathrm{CN}\right) \delta 149.27,148.87$.

Synthesis of Resin Loaded with DNA/DNA Triazole Nucleoside (17). Activated resin $16^{28}$ (500 mg) was soaked in anhydrous pyridine $(1 \mathrm{~mL})$ for $10 \mathrm{~min}$. EDC $(170 \mathrm{mg}, 1.09$ mmol), DMAP (36 mg, $0.29 \mathrm{mmol})$, triethylamine $(44 \mu \mathrm{L}, 0.32$ $\mathrm{mmol})$, and dinucleoside $8(56 \mathrm{mg}, 59 \mu \mathrm{mol})$ were added to the resin. The reaction vessel was rotated for $20 \mathrm{~h}$ at room temperature, after which pentachlorophenol $(26 \mathrm{mg}, 98 \mu \mathrm{mol})$ was added and the vessel was rotated for an additional $3 \mathrm{~h}$. The solvents were removed by filtration, and the support was washed with pyridine, $\mathrm{CH}_{2} \mathrm{Cl}_{2}$, and diethyl ether. Piperdine (10\% in DMF, $2 \mathrm{~mL}$ ) was added and the vessel was rotated for $5 \mathrm{~min}$ at room temperature. The solvent was removed by filtration and the support was washed with $\mathrm{CH}_{2} \mathrm{Cl}_{2}$ and diethyl ether. Capping reagent (oligonucleotide synthesis grade, acetic anhydride/pyridine/THF: $N$-methylimidazole in THF, 1:1, 2 $\mathrm{mL}$ ) was added and the vessel was rotated at room temperature for $1 \mathrm{~h}$. The solvent was removed by filtration, and the resin was washed with pyridine, $\mathrm{CH}_{2} \mathrm{Cl}_{2}$, and diethyl ether and dried under high vacuum overnight to obtain 17 . The loading of nucleoside 8 on the support was determined by cleaving the DMTr group and was found to be $28 \mu \mathrm{mol} / \mathrm{g}$.

Synthesis of Resin Loaded with DNA/LNA Triazole Nucleoside (18). Activated resin $16^{28}$ (800 mg) was soaked in anhydrous pyridine $(1 \mathrm{~mL})$ for $10 \mathrm{~min}$. EDC (0.329 g, 2.12 mmol), DMAP (14 mg, $0.11 \mathrm{mmol})$, triethylamine $(85 \mu \mathrm{L}, 0.61$ $\mathrm{mmol})$, and compound $9(100 \mathrm{mg}, 0.102 \mathrm{mmol})$ were added to the resin. The reaction vessel was rotated for $20 \mathrm{~h}$ at room temperature, after which pentachlorophenol (49 mg, 0.18 $\mathrm{mmol}$ ) was added and the vessel was rotated for an additional 3 $h$. The solvents were removed by filtration, and the support was washed with pyridine, $\mathrm{CH}_{2} \mathrm{Cl}_{2}$, and diethyl ether. Piperdine ( $10 \%$ in DMF, $2 \mathrm{~mL}$ ) was added and the vessel was rotated for $5 \mathrm{~min}$ at room temperature. The solvent was removed by filtration and the support was washed with $\mathrm{CH}_{2} \mathrm{Cl}_{2}$ and diethyl ether. Capping reagent (oligonucleotide synthesis grade, acetic anhydride/pyridine/THF: $N$-methylimidazole in THF, 1:1, 2 $\mathrm{mL}$ ) was added and the vessel was rotated at room temperature for $1 \mathrm{~h}$. The solvent was removed by filtration, and the resin was washed with pyridine, $\mathrm{CH}_{2} \mathrm{Cl}_{2}$, and diethyl ether and dried under high vacuum overnight. The loading of nucleoside 9 on the support was determined by cleaving the DMTr group and was found to be $26 \mu \mathrm{mol} / \mathrm{g}$.

Synthesis of Resin Loaded with LNA/DNA Triazole Nucleoside (19). Activated resin $16^{28}$ (300 mg) was soaked in $1 \mathrm{~mL}$ of anhydrous pyridine for $10 \mathrm{~min}$. EDC (0.132 g, 0.850 mmol), DMAP (6 mg, $49 \mu \mathrm{mol})$, triethylamine $(34 \mu \mathrm{L}, 0.24$ $\mathrm{mmol})$, and compound $10(40 \mathrm{mg}, 41 \mu \mathrm{mol})$ were added to the resin. The reaction vessel was rotated for $20 \mathrm{~h}$ at room temperature, after which pentachlorophenol $(20 \mathrm{mg}, 75 \mu \mathrm{mol})$ was added and the vessel was rotated for an additional $3 \mathrm{~h}$. The solvents were removed by filtration, and the support was washed with pyridine, $\mathrm{CH}_{2} \mathrm{Cl}_{2}$, and diethyl ether. Piperdine ( $10 \%$ in DMF, $2 \mathrm{~mL}$ ) was added and the vessel was rotated for $5 \mathrm{~min}$ at room temperature. The solvent was removed by filtration and the support was washed with $\mathrm{CH}_{2} \mathrm{Cl}_{2}$ and diethyl ether. Capping reagent (oligonucleotide synthesis grade, acetic anhydride/pyridine/THF:N-methylimidazole in THF, 1:1, 2 $\mathrm{mL}$ ) was added and the vessel was rotated at room temperature for $1 \mathrm{~h}$. The solvent was removed by filtration and the resin was washed with pyridine, $\mathrm{CH}_{2} \mathrm{Cl}_{2}$, and diethyl ether and dried under high vacuum overnight. The loading of nucleoside 10 on the support was determined by cleaving the DMTr group and was found to be $29 \mu \mathrm{mol} / \mathrm{g}$.

Synthesis of Resin Loaded with LNA/LNA Triazole Nucleoside (20). Activated resin $16^{28}(250 \mathrm{mg})$ was soaked in $1 \mathrm{~mL}$ of anhydrous pyridine for $10 \mathrm{~min}$. EDC (0.106 g, 0.683 mmol), DMAP (5 mg, $41 \mu \mathrm{mol})$, triethylamine $(28 \mu \mathrm{L}, 0.20$ $\mathrm{mmol}$ ), and compound 11 (33 mg, $33 \mu \mathrm{mol}$ ) were added to the resin. The reaction vessel was rotated for $20 \mathrm{~h}$ at room temperature, after which pentachlorophenol $(16 \mathrm{mg}, 60 \mu \mathrm{mol})$ was added and the vessel was rotated for an additional $3 \mathrm{~h}$. The solvents were removed by filtration, and the support was washed with pyridine, $\mathrm{CH}_{2} \mathrm{Cl}_{2}$, and diethyl ether. Piperdine (10\% in DMF, $2 \mathrm{~mL}$ ) was added and the vessel was rotated for $5 \mathrm{~min}$ at room temperature. The solvent was removed by filtration and the support was washed with $\mathrm{CH}_{2} \mathrm{Cl}_{2}$ and diethyl ether. Capping reagent (oligonucleotide synthesis grade, acetic anhydride/pyridine/THF:N-methylimidazole in THF, 1:1, 2 $\mathrm{mL}$ ) was added and the vessel was rotated at room temperature for $1 \mathrm{~h}$. The solvent was removed by filtration and the resin was washed with pyridine, $\mathrm{CH}_{2} \mathrm{Cl}_{2}$, and diethyl ether and dried under high vacuum overnight. The loading of nucleoside 11 on the support was determined by cleaving the DMTr group and was found to be $28 \mu \mathrm{mol} / \mathrm{g}$.

Synthesis of Oligonucleotides. Standard DNA phosphoramidites, solid supports, and reagents were purchased from Link Technologies and Applied Biosystems. LNA phosphoramidites were obtained from Exiqon. Automated solid-phase synthesis of oligonucleotides (trityl off) was performed on an Applied Biosystems 394 synthesizer. The synthesis was performed on $1.0 \mu \mathrm{m}$ scale involving cycles of acid-catalyzed detritylation, coupling, capping, and iodine oxidation. Standard DNA phosphoramidites were coupled for $60 \mathrm{~s}$, whereas extended coupling time of $10 \mathrm{~min}$ was used for the modified phosphoramidites including LNA phosphoramidites. Modified phosphoramidites $12,13,14$, and 15 were used to prepare ONs with monomers $\mathbf{W}, \mathbf{X}, \mathbf{Y}$, and $\mathbf{Z}$ respectively. Coupling efficiencies and overall synthesis yields were determined by the inbuilt automated trityl cation conductivity monitoring facility and were $\geq 98.0 \%$ in all the cases. The oligonucleotides were then cleaved from the solid support and protecting groups from the nucleobase and backbone were removed by exposure to concentrated aqueous ammonium hydroxide for $60 \mathrm{~min}$ at room temperature followed by heating in a sealed tube for $5 \mathrm{~h}$ at $55{ }^{\circ} \mathrm{C}$. RNA was purchased from Integrated DNA Technologies BVBA, Leuven, Belgium.

Purification of Oligonucleotides. The fully deprotected oligonucleotides were then purified by reverse-phase highperformance liquid chromatography (HPLC) on a Gilson system using a Luna $10 \mu \mathrm{m} \mathrm{C8}(2) 100 \AA$ pore Phenomenex column $\left(250 \times 10 \mathrm{~mm}^{2}\right)$ with a gradient of acetonitrile in triethylammonium bicarbonate (TEAB) over $20 \mathrm{~min}$ at a flow rate of $4 \mathrm{~mL} / \mathrm{min}$. Buffer A: 0.1 M TEAB, $\mathrm{pH} 7.5$; buffer B: 0.1 $\mathrm{M}$ TEAB, $\mathrm{pH} 7.5$, with $50 \%$ acetonitrile were used. Elution was monitored by UV absorption between 260 and $295 \mathrm{~nm}$. A gradient of acetonitrile in hexylammonium acetate (HAA) over $20 \mathrm{~min}$ at a flow rate of $4 \mathrm{~mL} / \mathrm{min}$ was used to purify 
oligonucleotides, which were not separable using a gradient of acetonitrile in TEAB. Buffer A: 0.1 M HAA, $\mathrm{pH} 7.5$; buffer B: $0.1 \mathrm{M}$ TEAB, $\mathrm{pH} 7.5$, with $50 \%$ acetonitrile were used. The elution was monitored by UV absorption between 260 and 298 nm.

Thermal Denaturation Experiments. UV DNA melting curves were recorded in a Cary 4000 Scan UV-vis spectrophotometer using $3 \mu \mathrm{M}$ of each oligonucleotide in a $10 \mathrm{mM}$ phosphate buffer containing $200 \mathrm{mM} \mathrm{NaCl}$ at $\mathrm{pH}$ 7.0. The samples were annealed by heating to $85{ }^{\circ} \mathrm{C}\left(10{ }^{\circ} \mathrm{C} / \mathrm{min}\right)$ and then slowly cooling to $20{ }^{\circ} \mathrm{C}\left(1{ }^{\circ} \mathrm{C} / \mathrm{min}\right)$. Six successive cycles (heating and cooling) were performed at a gradient of 1 ${ }^{\circ} \mathrm{C} / \mathrm{min}$ and the change in UV absorbance at $260 \mathrm{~nm}$ was recorded. The melting temperature was calculated from the first derivative of the melting curve using an in-built software.

Snake Venom Phosphodiesterase Stability. Five nanomole of oligonucleotide was dissolved in $100 \mu \mathrm{L}$ buffer $(50 \mathrm{mM}$ Tris- $\mathrm{HCl}, 10 \mathrm{mM} \mathrm{MgCl} 2, \mathrm{pH}=9.0)$. Twenty microliter of this solution was removed as a control $(0 \mathrm{~min})$. To the remaining solution was added $2 \mu \mathrm{L}$ aqueous solution of phosphodiesterase 1 from C. adamanteus venom (from Sigma-Aldrich, catalogue number P3243, 0.45 units, dissolved in $7 \mathrm{~mL} \mathrm{H}_{2} \mathrm{O}$ ). The reaction was incubated at $37{ }^{\circ} \mathrm{C}$ and aliquots $(20 \mu \mathrm{L})$ were taken at different time intervals, mixed with formamide (20 $\mu \mathrm{L}$ ), and stored at $-20^{\circ} \mathrm{C}$. The samples were then analyzed by denaturing $20 \%$ polyacrylamide gel electrophoresis.

Serum Stability. Five nanomole of oligonucleotide was dissolved in $50 \mu \mathrm{L}$ Dulbecco's PBS and $50 \mu \mathrm{L}$ of FBS (Gibco, standard (sterile-filtered)) was added. The sample was thoroughly mixed by vortexing before $20 \mu \mathrm{L}$ of this solution was removed, mixed with formamide $(20 \mu \mathrm{L})$, and stored at $-80{ }^{\circ} \mathrm{C}$ as a control $(0 \mathrm{~h})$. The remaining reaction mixtures were incubated at $37{ }^{\circ} \mathrm{C}$ and aliquots $(20 \mu \mathrm{L})$ were taken at different time intervals, mixed with formamide $(20 \mu \mathrm{L})$, and stored at $-80{ }^{\circ} \mathrm{C}$. The samples were then analyzed by denaturing $20 \%$ polyacrylamide gel.

CD Spectroscopy. CD spectra (200-340 nm) were recorded on a Chirscan Plus spectropolarimeter using a quartz optical cells with a path length of $5.0 \mathrm{~mm}$. The scans were performed at $10{ }^{\circ} \mathrm{C}$ using a step size of $0.5 \mathrm{~nm}$, a time per point of $1.0 \mathrm{~s}$, and a bandwidth of $2 \mathrm{~nm}$; the average of four scans is presented. Duplexes were prepared by mixing $3 \mu \mathrm{M}$ of each oligonucleotide in a $10 \mathrm{mM}$ phosphate buffer containing 200 $\mathrm{mM} \mathrm{NaCl}$ at $\mathrm{pH} 7.0$ and annealed by heating to $85^{\circ} \mathrm{C}$ and then slowly cooled to $10{ }^{\circ} \mathrm{C}$ before recording the $\mathrm{CD}$ spectrum. A $\mathrm{CD}$ spectrum of the buffer alone was recorded and subtracted from the collected data.

\section{ASSOCIATED CONTENT}

\section{S Supporting Information}

The Supporting Information is available free of charge on the ACS Publications website at DOI: 10.1021/acsomega.8b01086.

Mass spectrometry data for modified oligonucleotides, additional oligonucleotide duplex melting data, additional oligonucleotide enzymatic digestion studies, HPLC analysis of modified oligonucleotides, NMR spectra of compounds (PDF)

\section{AUTHOR INFORMATION}

\section{Corresponding Author}

*E-mail: tom.brown@chem.ox.ac.uk.

\section{ORCID}

Pawan Kumar: 0000-0001-7936-4613

Afaf Helmy El-Sagheer: 0000-0001-8706-1292

Tom Brown: 0000-0002-6538-3036

\section{Present Address}

${ }^{\S}$ Alnylam Pharmaceuticals, 300 Third Street, Cambridge, Massachusetts 02142, United States. E-mail: pkumar@ alnylam.com (P.K.).

\section{Notes}

The authors declare no competing financial interest.

\section{ACKNOWLEDGMENTS}

Authors acknowledge the generous funding U.K. BBSRC grants $\mathrm{BB} / \mathrm{J} 001694 / 2$ (extending the boundaries of nucleic acid chemistry). P.K. holds a Marie Sklodowska-Curie Individual Fellowship from European Commission, L.T. was funded by the intramural program of the National Heart, Lung and Blood Institute, NIH, United States, through the NIH-OxfordCambridge Research Scholars Program.

\section{REFERENCES}

(1) Rinaldi, C.; Wood, M. J. A. Antisense oligonucleotides: the next frontier for treatment of neurological disorders. Nat. Rev. Neurol. 2018, 14, 9-21.

(2) Wan, W. B.; Seth, P. P. The Medicinal Chemistry of Therapeutic Oligonucleotides. J. Med. Chem. 2016, 59, 9645-9667.

(3) Kurreck, J. Antisense technologies. Eur. J. Biochem. 2003, 270, $1628-1644$

(4) Deleavey, G. F.; Damha, M. J. Designing Chemically Modified Oligonucleotides for Targeted Gene Silencing. Chem. Biol. 2012, 19, 937-954.

(5) Zamecnik, P. C.; Stephenson, M. L. Inhibition of Rous sarcoma virus replication and cell transformation by a specific oligodeoxynucleotide. Proc. Natl. Acad. Sci. U.S.A. 1978, 75, 280-284.

(6) Khvorova, A.; Watts, J. K. The chemical evolution of oligonucleotide therapies of clinical utility. Nat. Biotechnol. 2017, 35, 238-248.

(7) Stein, C. A.; Castanotto, D. FDA-Approved Oligonucleotide Therapies in 2017. Mol. Ther. 2017, 25, 1069-1075.

(8) El-Sagheer, A. H.; Brown, T. Click nucleic acid ligation: Applications in biology and nanotechnology. Acc. Chem. Res. 2012, $45,1258-1267$.

(9) El-Sagheer, A. H.; Brown, T. Efficient RNA synthesis by in vitro transcription of a triazole-modified DNA template. Chem. Commun. 2011, 47, 12057-12058.

(10) El-Sagheer, A. H.; Sanzone, A. P.; Gao, R.; Tavassoli, A.; Brown, T. Biocompatible artificial DNA linker that is read through by DNA polymerases and is functional in E.coli. Proc. Natl. Acad. Sci. U.S.A. 2011, 108, 11338-11343.

(11) Birts, C. N.; Sanzone, A. P.; El-Sagheer, A. H.; Blaydes, J. P.; Brown, T.; Tavassoli, A. Transcription of click-linked DNA in human cells. Angew. Chem., Int. Ed. 2014, 53, 2362-2365.

(12) Shivalingam, A.; Tyburn, A. E. S.; El-Sagheer, A. H.; Brown, T. Molecular Requirements of High-Fidelity Replication-Competent DNA Backbones for Orthogonal Chemical Ligation. J. Am. Chem. Soc. 2017, 139, 1575-1583.

(13) Isobe, H.; Fujino, T.; Yamazaki, N.; Guillot-Nieckowski, M.; Nakamura, E. Triazole-linked analogue of deoxyribonucleic acid ( $\left.{ }^{\mathrm{TL}} \mathrm{DNA}\right)$ : Design, synthesis, and double-strand formation with natural DNA. Org. Lett. 2008, 10, 3729-3732.

(14) Isobe, H.; Fujino, T. Triazole-linked analogues of DNA and RNA (TLDNA and TLRNA): Synthesis and functions. Chem. Rec. 2014, 14, 41-51.

(15) Sharma, V. K.; Singh, S. K.; Krishnamurthy, P. M.; Alterman, J. F.; Haraszti, R. A.; Khvorova, A.; Prasad, A. K.; Watts, J. K. Synthesis 
and biological properties of triazole-linked locked nucleic acid. Chem. Commun. 2017, 53, 8906-8909.

(16) Kumar, P.; El-Sagheer, A. H.; Truong, L.; Brown, T. Locked nucleic acid (LNA) enhances binding affinity of triazole-linked DNA towards RNA. Chem. Commun. 2017, 53, 8910-8913.

(17) Varizhuk, A. M.; Kaluzhny, D. N.; Novikov, R. A.; Chizhov, A. O.; Smirnov, I. P.; Chuvilin, A. N.; Tatarinova, O. N.; Fisunov, G. Y.; Pozmogova, G. E.; Florentiev, V. L. Synthesis of Triazole-Linked Oligonucleotides with High Affinity to DNA Complements and an Analysis of Their Compatibility with Biosystems. J. Org. Chem. 2013, 78, 5964-5969.

(18) Varizhuk, A. M.; Tsvetkov, V. B.; Tatarinova, O. N.; Kaluzhny, D. N.; Florentiev, V. L.; Timofeev, E. N.; Shchyolkina, A. K.; Borisova, O. F.; Smirnov, I. P.; Grokhovsky, S. L.; Aseychev, A. V.; Pozmogova, G. E. Synthesis, characterization and in vitro activity of thrombinbinding DNA aptamers with triazole internucleotide linkages. Eur. J. Med. Chem. 2013, 67, 90-97.

(19) Madhuri, V.; Kumar, V. A. Design and synthesis of dephosphono DNA analogues containing 1,2,3-triazole linker and their UV-melting studies with DNA/RNA. Nucleosides, Nucleotides Nucleic Acids 2012, 31, 97-111.

(20) Dallmann, A.; El-Sagheer, A. H.; Dehmel, L.; Mügge, C.; Griesinger, C.; Ernsting, N. P.; Brown, T. Structure and dynamics of triazole-linked DNA: Biocompatibility explained. Chem. - Eur. J. 2011, 17, 14714-14717.

(21) Varizhuk, A.; Chizhov, A.; Smirnov, I.; Kaluzhny, D.; Florentiev, V. Triazole-Linked Oligonucleotides with Mixed-Base Sequences: Synthesis and Hybridization Properties. Eur. J. Org. Chem. 2012, 2012, $2173-2179$.

(22) Varizhuk, A.; Chizhov, A.; Florentiev, V. Synthesis and hybridization data of oligonucleotide analogs with triazole internucleotide linkages, potential antiviral and antitumor agents. Bioorg. Chem. 2011, 39, 127-131.

(23) Fujino, T.; Kogashi, K.; Okada, K.; Mattarella, M.; Suzuki, T.; Yasumoto, K.; Sogawa, K.; Isobe, H. Chimeric RNA Oligonucleotides with Triazole and Phosphate Linkages: Synthesis and RNA Interference. Chem. - Asian J. 2015, 10, 2683-2688.

(24) Vester, B.; Wengel, J. LNA (Locked Nucleic Acid): HighAffinity Targeting of Complementary RNA and DNA. Biochemistry 2004, 43, 13233-13241.

(25) Singh, S. K.; Nielsen, P.; Koshkin, A. A.; Wengel, J. LNA (locked nucleic acids): Synthesis and high-affinity nucleic acid recognition. Chem. Commun. 1998, 4, 455-456.

(26) Obika, S.; Nanbu, D.; Hari, Y.; Andoh, J. I.; Morio, K. I.; Doi, T.; Imanishi, T. Stability and structural features of the duplexes containing nucleoside analogues with a fixed $\mathrm{N}$-type conformation, 2 'O,4'-C- methyleneribonucleosides. Tetrahedron Lett. 1998, 39, 54015404.

(27) Kaur, H.; Babu, B. R.; Maiti, S. Perspectives on Chemistry and Therapeutic Applications of Locked Nucleic Acid (LNA). Chem. Rev. 2007, 107, 4672-4697.

(28) El-Sagheer, A. H.; Brown, T. New strategy for the synthesis of chemically modified RNA constructs exemplified by hairpin and hammerhead ribozymes. Proc. Natl. Acad. Sci. U.S.A. 2010, 107, 15329-15334.

(29) Koshkin, A. A.; Fensholdt, J.; Pfundheller, H. M.; Lomholt, C. A simplified and efficient route to $2^{\prime}$-O, 4'-C-methylene-linked bicyclic ribonucleosides (locked nucleic acid). J. Org. Chem. 2001, 66, 85048512.

(30) Said, H.; Guttroff, C.; El-Sagheer, A. H.; Richert, C. Two-Step Synthesis of a 5'-Azidothymidine Building Block for the Assembly of Oligonucleotides for Triazole-Forming Ligations. Synlett 2012, 23, 2923-2926.

(31) Rostovtsev, V. V.; Green, L. G.; Fokin, V. V.; Sharpless, K. B. A stepwise Huisgen cycloaddition process: Copper(I)-catalyzed regioselective "ligation" of azides and terminal alkynes. Angew. Chem., Int. Ed. 2002, 41, 2596-2599.

(32) Tornøe, C. W.; Christensen, C.; Meldal, M. Peptidotriazoles on solid phase: [1,2,3]-Triazoles by regiospecific copper(I)-catalyzed 1,3- dipolar cycloadditions of terminal alkynes to azides. J. Org. Chem. 2002, 67, 3057-3064.

(33) Owczarzy, R; You, Y.; Groth, C. L.; Tataurov, A. V. Stability and Mismatch Discrimination of Locked Nucleic Acid-DNA Duplexes. Biochemistry 2011, 50, 9352-9367.

(34) Bondensgaard, K.; Petersen, M.; Singh, S. K.; Rajwanshi, V. K.; Kumar, R.; Wengel, J.; Jacobsen, J. P. Structural Studies of LNA:RNA Duplexes by NMR: Conformations and Implications for RNase H Activity. Chem. - Eur. J. 2000, 6, 2687-2695.

(35) Sanzone, A. P.; El-Sagheer, A. H.; Brown, T.; Tavassoli, A. Assessing the biocompatibility of click-linked DNA in Escherichia coli. Nucleic Acids Res. 2012, 40, 10567-10575.

(36) Havens, M. A.; Hastings, M. L. Splice-switching antisense oligonucleotides as therapeutic drugs. Nucleic Acids Res. 2016, 44, $6549-6563$ 